\title{
A comparative analysis of the effectiveness of flood management measures based on the concept of "retaining water in the landscape" in different European hydro-climatic regions
}

\author{
S. Salazar ${ }^{1}$, F. Francés ${ }^{1}$, J. Komma ${ }^{2}$, T. Blume ${ }^{3}$, T. Francke ${ }^{4}$, A. Bronstert ${ }^{4}$, and G. Blöschl ${ }^{2}$ \\ ${ }^{1}$ Research Institute of Water Engineering and Environment, Technical University of Valencia, Camino de Vera s/n, \\ 46022 Valencia, Spain \\ ${ }^{2}$ Institute of Hydraulic Engineering and Water Resources Management, Vienna University of Technology, Karlsplatz 13/222, \\ 1040 Vienna, Austria \\ ${ }^{3}$ GFZ German Research Centre for Geosciences, Section 5.4 Hydrology, Telegrafenberg, 14473 Potsdam, Germany \\ ${ }^{4}$ Institute of Earth and Environmental Science, Chair for Hydrology and Climatology, University of Potsdam, \\ Karl-Liebknecht-Str. 24-25, 14476 Potsdam-Golm, Germany
}

Correspondence to: F. Francés (ffrances@hma.upv.es)

Received: 2 May 2012 - Revised: 18 September 2012 - Accepted: 27 September 2012 - Published: 12 November 2012

\begin{abstract}
In this paper, we analyse the effectiveness of flood management measures based on the concept known as "retaining water in the landscape". The investigated measures include afforestation, micro-ponds and small-reservoirs. A comparative and model-based methodological approach has been developed and applied for three meso-scale catchments located in different European hydro-climatological regions: Poyo $\left(184 \mathrm{~km}^{2}\right)$ in the Spanish Mediterranean, Upper Iller $\left(954 \mathrm{~km}^{2}\right)$ in the German Alps and Kamp $\left(621 \mathrm{~km}^{2}\right)$ in Northeast-Austria representing the Continental hydroclimate. This comparative analysis has found general similarities in spite of the particular differences among studied areas. In general terms, the flood reduction through the concept of "retaining water in the landscape" depends on the following factors: the storage capacity increase in the catchment resulting from such measures, the characteristics of the rainfall event, the antecedent soil moisture condition and the spatial distribution of such flood management measures in the catchment. In general, our study has shown that, this concept is effective for small and medium events, but almost negligible for the largest and less frequent floods: this holds true for all different hydro-climatic regions, and with different landuse, soils and morphological settings.
\end{abstract}

\section{Introduction}

Flood management measures are actions that are taken to reduce either the probability of flooding or the consequences of flooding or some combination of the two (Samuels et al., 2009). Pre-flood preparedness, as one of the components of holistic flood management (Kundzewicz and Takeuchi, 1999), involves decisions for future planning that could produce long-term environmental changes. Here, the concept of change is central to both the processes involved as well as the methodologies used in their analysis (Bronstert, 2004; Blöschl et al., 2007). Hydrological processes are a key consideration when characterising floods during the hazard determination stage and in subsequent risk analysis (Schumann, 2011). The methodology used for flood management planning must be able to distinguish broad strategic options and it requires an approximate precision of information to support decisions (Hall et al., 2003). For this purpose, hydrological models should be used because they are able to reflect landscape characteristics as well as hydrological scales (Plate, 2009).

The representation of flood management measures in hydrological modelling makes it necessary to address the problem of changing conditions at the same location. It is one of the problems of model transposability (Klemeš, 1986). To this end, the scenario approach is one of the most frequently used techniques in environmental studies due to its 
flexibility and future-orientation. It offers an opportunity for assessment of the present and possible future situation, but bearing in mind that it is to be understood as a projection rather than a prediction (Niehoff et al., 2002). If the same relevant hydrological processes are assumed, we can use validated models to assess the impact of changed pressure conditions responding to a known system (Klöcking and Haberlandt, 2002). Then, a calibrated and validated model can be used as reference to analyse a new scenario (Wegehenkel, 2002). Assuming a hydrological model which represents the dominant processes operating in a catchment under current conditions, the following considerations are of particular importance: (i) deciding which model parameters will change, and (ii) the extent to which the new characteristics of the altered system should be reflected (Wagener, 2007).

The knowledge of the effectiveness of various measures is the basis for designing an efficient strategy in the context of flood management (Hooijer et al., 2004). An indicator to evaluate the measure effectiveness will be via peak discharge reduction because it will contribute to evaluating the attainment of the flooding probability reduction. Regarding this indicator, there is an important body of literature on individual catchments and individual measures, but there are few comparative studies regarding several measures, scales and places simultaneously. Two published integrated modelling projects applied on large scale river basins were carried out in the Rhine and Meuse rivers by Hooijer et al. (2004) and by Bronstert et al. (2007) for the Rhine basin. Both groups concluded that upstream water retention measures, along channels or through land use changes, can significantly reduce the frequency of small and intermediate floods in small basins, or contribute to the reduction of medium floods in large basins. However, no significant effect was noted in extreme flood events occurring in large basins and far downstream. Changes induced by similar measures on hydrological processes in a particular catchment may or may not appear to be similar to those experienced in another catchment with different characteristics. Wagener et al. (2010) call for an interdisciplinary collaborative effort to help understand changes across locations and spatiotemporal scales through a "comparative hydrology" which help us to understand the spatial variability of system behaviour and its controls. On this basis, this approach would help with understanding similarities and identifying dissimilarities.

The aim of this paper is to carry out a combination of comparative hydrological analysis with scenario based modelling, to assess the effectiveness of three flood management measures, in terms of their capacity for peak discharge reduction. To do so, we analyse a set of particular pre-flood preparedness measures, based on the concept of "retaining water in the landscape", in order to assess its possible role in achieving the goals of the EU Flood Directive. Within this concept, we evaluate source control measures through the alteration of runoff generation processes in the catchment and runoff routing mechanisms, both in the catchment hillslopes and in the headwater channel networks. Measures to prevent flood generation and preventive flood control measures were those identified in the classification given by Hooijer et al. (2004). In this sense, effects on flood characteristics will be expected, especially a reduction in peak discharges.

Three types of measures are often part of this flood mitigation strategy: afforestation, ponds and small-reservoirs. Afforestation was introduced in several catchment policies, such as in the Elbe river basin (Wahren et al., 2007) and the Rhine river basin (Disse and Engel, 2001). Ponds are valuable elements in both local and regional landscapes, because they can help fulfil a variety of goals in flood control, water quality and ecological or agricultural functions (De Laney, 1995). A cascade of reservoirs is more effective in terms of peak delay than a single reservoir with the same storage capacity, because this system tends to generate a multi-peaked hydrograph (Valdes and Marco, 1995); thereby reductions in maximum peak discharges will be expected. Also, a set of small dams (maximum height $15 \mathrm{~m}$ ) with small reservoirs (maximum volume $100000 \mathrm{~m}^{3}$ ) may reduce both the environmental impacts of such engineering works as well as the severity of potential downstream damages through a dam failure.

The aim of this paper is based on the following scientific questions: (i) what are the differences in terms of effectiveness among these types of measures? and (ii) which factors control these differences?. To answer these, we have analysed the hydrological processes in three catchments with significant differences (in terms of size, climate, land cover, soil and hydrogeology), using distributed hydrological models and a scenario approach, i.e., assuming current conditions as a reference situation and the scenarios reflecting the preflood measures proposed in future planning. In order to focus on the dominant mechanism for runoff generation, we have chosen three meso-scale catchments where flood wave routing in the floodplain does not affect the discharge at the catchment outlet (Bronstert et al., 2007) and where hydrological modelling is considered to be a very useful and appropriate tool (Hundecha and Bárdossy, 2004; Plate, 2009).

The paper is organised as follows. Section 2 presents a brief description of each study area in terms of their main physical characteristics. Section 3 gives a description of each hydrological model, followed by the methodology for the parameterisation of flood management scenarios (Sect. 4). Section 5 presents the results and discusses them in terms of the methodology applied and the effectiveness of the pre-flood measures proposed. Section 6 presents the conclusions and some final recommendations.

\section{Study areas}

Three different case studies were selected according to the classification of hydro-climatological regions of Europe. All of them are characterised by different climate, vegetation, 


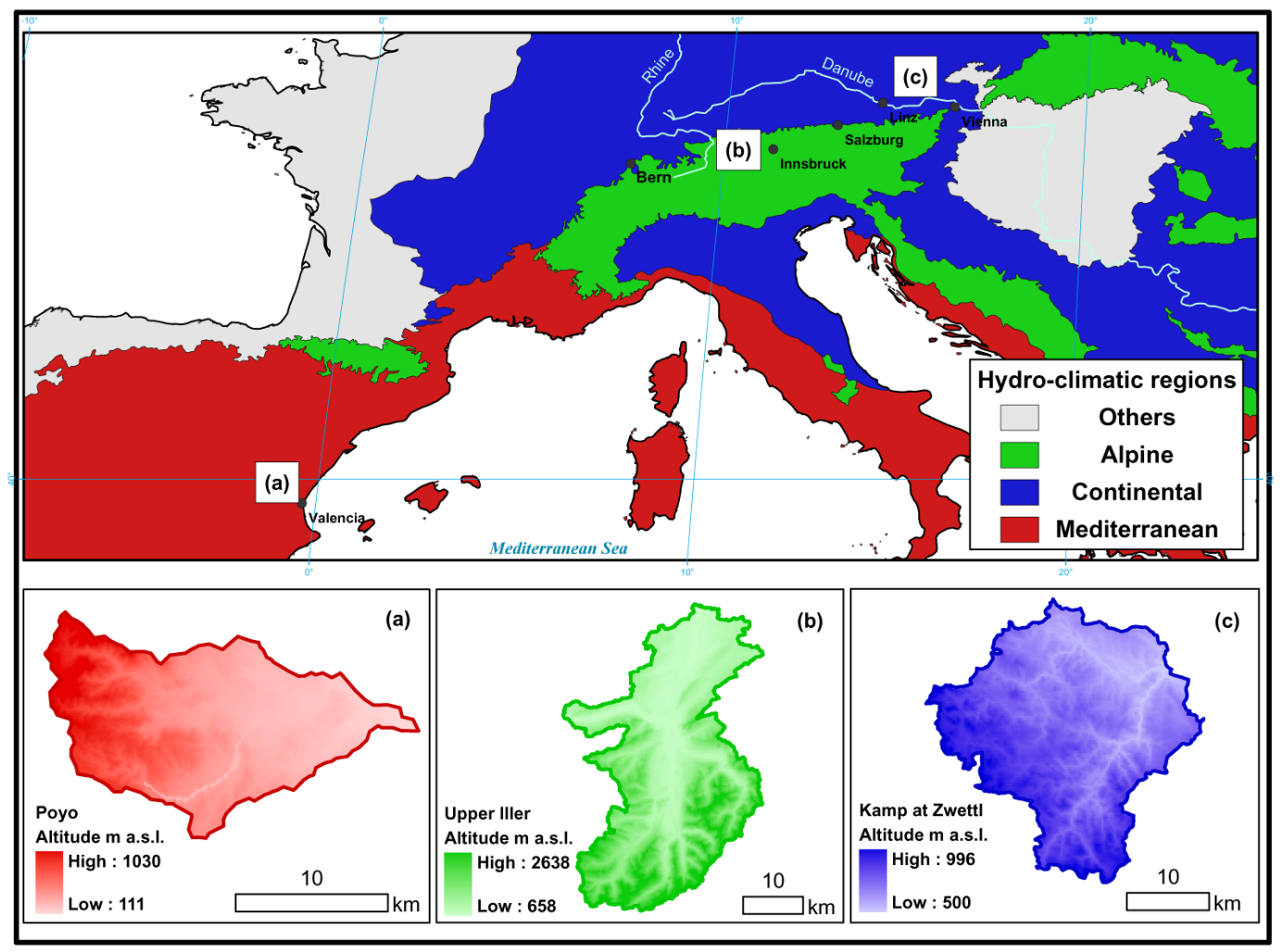

Fig. 1. Location of the studied catchments: (a) Poyo, (b) Upper Iller and (c) Kamp. Hydro-climatic regions adapted from European Biogeographical regions map (Source: European Environment Agency).

soils, hydrogeology and flood processes. Figure 1 shows the location of the catchments from left to right: (a) the "Rambla del Poyo" on the East coast of Spain; (b) "Upper Iller River" in Southern Germany in an alpine region close to the Austrian border; and (c) "Kamp River" in north-eastern Austria close to the Czech border. In the same order, catchment drainage areas are $184 \mathrm{~km}^{2}, 954 \mathrm{~km}^{2}$ and $621 \mathrm{~km}^{2}$, representing the Mediterranean, Alpine and Continental European hydro-climatological regions, respectively. There are a number of differences in topographical conditions, with altitudes ranging between 111 and $1030 \mathrm{~m}$ a.s.l. in Poyo, 500 and $996 \mathrm{~m}$ a.s.l. in Kamp and 658 and $2638 \mathrm{~m}$ a.s.l. in Upper Iller (see Fig. 1). Data from the $1 \mathrm{kmx} 1 \mathrm{~km}$ raster library of the European Soil Database (Panagos et al., 2012) have helped us to identify several parent material hydrogeological types (Fig. 2) and soil codes from the World Reference Base (Fig. 3). Land cover is also quite different across catchments, as can be seen in Fig. 4; there are different land cover classes which were obtained from CORINE Land Cover 2000 codes (CLC2000) at label 3. The catchments are briefly described in the following, while the main hydro-climatic characteristics are compiled in Table 1. Spatial characteristics extracted from European Soil Database and CLC2000 (Figs. 2, 3 and 4) are based on original sources from the national databases listed in Table 2. The spatial data shown in
Table 2 were used in each case study as explained in the next section.

The Poyo catchment is characterised by a semiarid Mediterranean climate, with a mean annual rainfall of about $450 \mathrm{~mm}$ and a potential evapotranspiration about $1100 \mathrm{~mm}$. The flow regime in Poyo catchment is typically ephemeral (i.e., without baseflow) and dominated by extreme rainfall events, whose intensity is the main cause of flash floods. The annual runoff coefficient is approximately $2 \%$, but Camarasa and Segura (2001) computed an average event-based runoff coefficient of about $8 \%$, which is highly variable. Camarasa and Segura (2001) found that as a function of rainfall characteristics and the synchronisation of tributaries, the responses can be either single high peak discharges (with low volumes and short duration) or multipeak discharges (with higher volumes and longer duration). Associated are to two distinct rainfall patterns: (i) convective cells that show the greatest intensity, shortest duration and fastest movement mainly over coastal areas, and (ii) persistent, larger cells showing intermediate intensity and slower movement over mountainous areas. The most important flood registered took place in October 2000, producing considerable damages in the floodplain area.

In the Upper Iller catchment, the mean annual precipitation is approximately $2000 \mathrm{~mm}$ with an annual runoff 

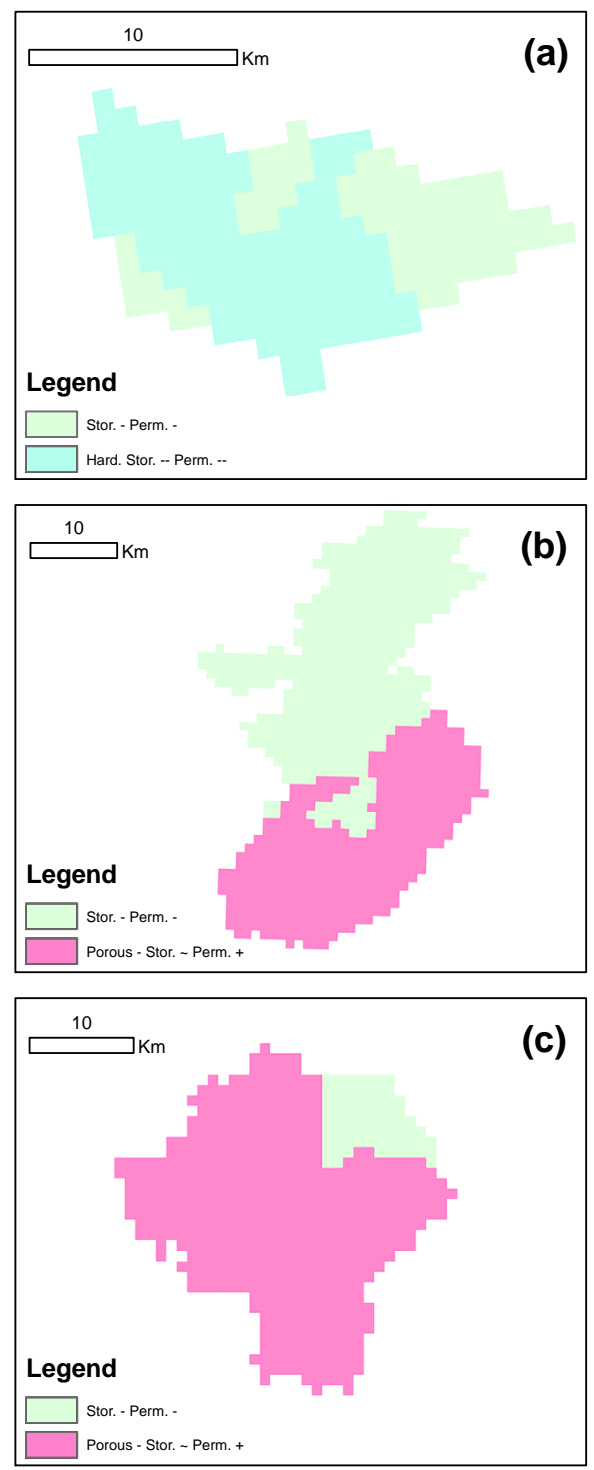

Fig. 2. Parent material hydrogeological types $(1 \mathrm{~km} \times 1 \mathrm{~km}$ raster library of the European Soil Database, Panagos et al., 2012) in the catchments: (a) Poyo, (b) Upper Iller and (c) Kamp. (Stor. - Perm. $-=$ weakly or unconsolidated microporous substratum with a low permeability and storage capacity. Hard. Stor. - Perm. $-=$ hard massive rock with negligible permeability and storage capacity. Porous - Stor. $\sim$ Perm. $+=$ hard, non- or weakly porous limestone, sandstone and crystalline rock with moderate storage capacity and high permeability because of well developed fissure/joint systems).

coefficient of about $78 \%$. It is noteworthy that, as precipitation is likely to be underestimated due to a bias in rain gauge locations to lower elevations, the runoff coefficient is likely to be overestimated. The average maximum annual flood flow is about $382 \mathrm{~m}^{3} \mathrm{~s}^{-1}$ and the average annual discharge is about $47 \mathrm{~m}^{3} \mathrm{~s}^{-1}$. The flow regime of the Iller can be characterised as alpine and sub-alpine with low flow in winter, high discharge during spring snowmelt and medium flow
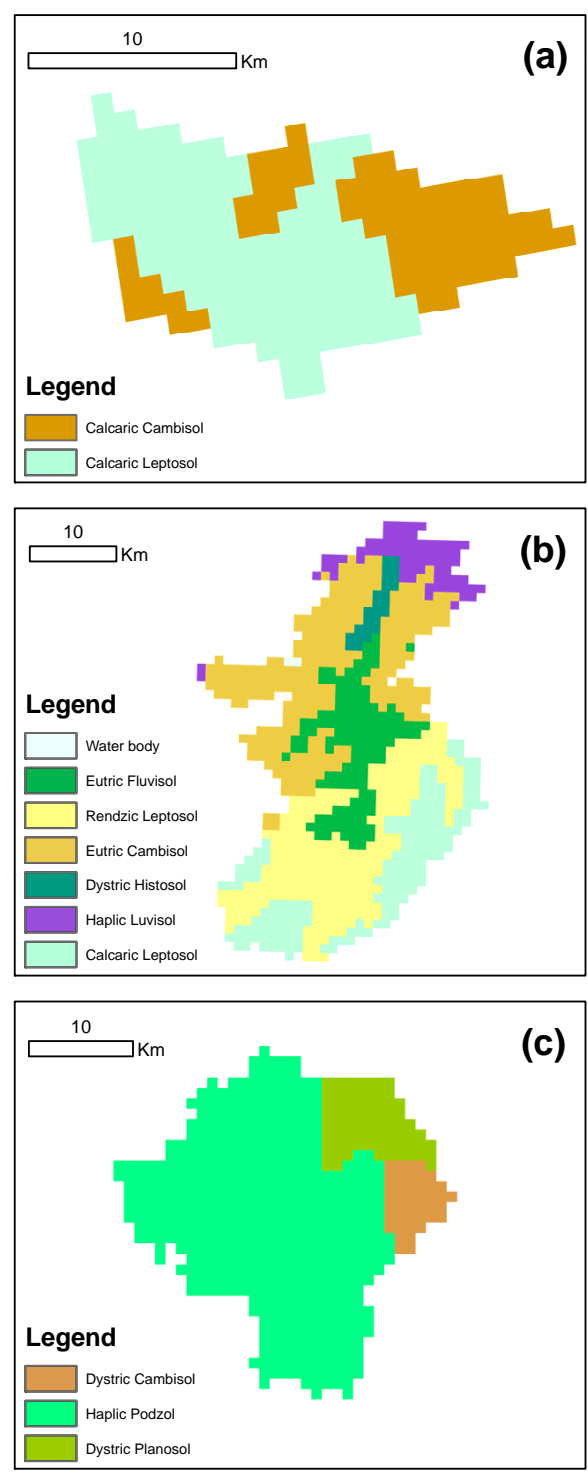

Fig. 3. Soil codes from the World Reference Base $(1 \mathrm{~km} \times 1 \mathrm{~km}$ raster library of the European Soil Database, Panagos et al., 2012) in the catchments: (a) Poyo, (b) Upper Iller and (c) Kamp.

in summer. The main flood season is summer, where heavy rainfall events lasting between 24 and $48 \mathrm{~h}$, usually orographically enhanced, can cause disastrous floods. The two largest floods ever recorded in over $100 \mathrm{yr}$ of record took place in May 1999 (peak discharge at Kempten gauge: $850 \mathrm{~m}^{3} \mathrm{~s}^{-1}$ ) and August 2005 (peak discharge $900 \mathrm{~m}^{3} \mathrm{~s}^{-1}$ ).

In the Kamp catchment, the mean annual precipitation is about $900 \mathrm{~mm}$ of which about $300 \mathrm{~mm}$ becomes runoff, i.e., the annual runoff coefficient is approximately $33 \%$ (Parajka et al., 2005). It is characterised by a range of flood processes, with the most important floods produced by synoptic events in which humid air is transported from the Mediterranean; this type of flood exhibits the largest flood 

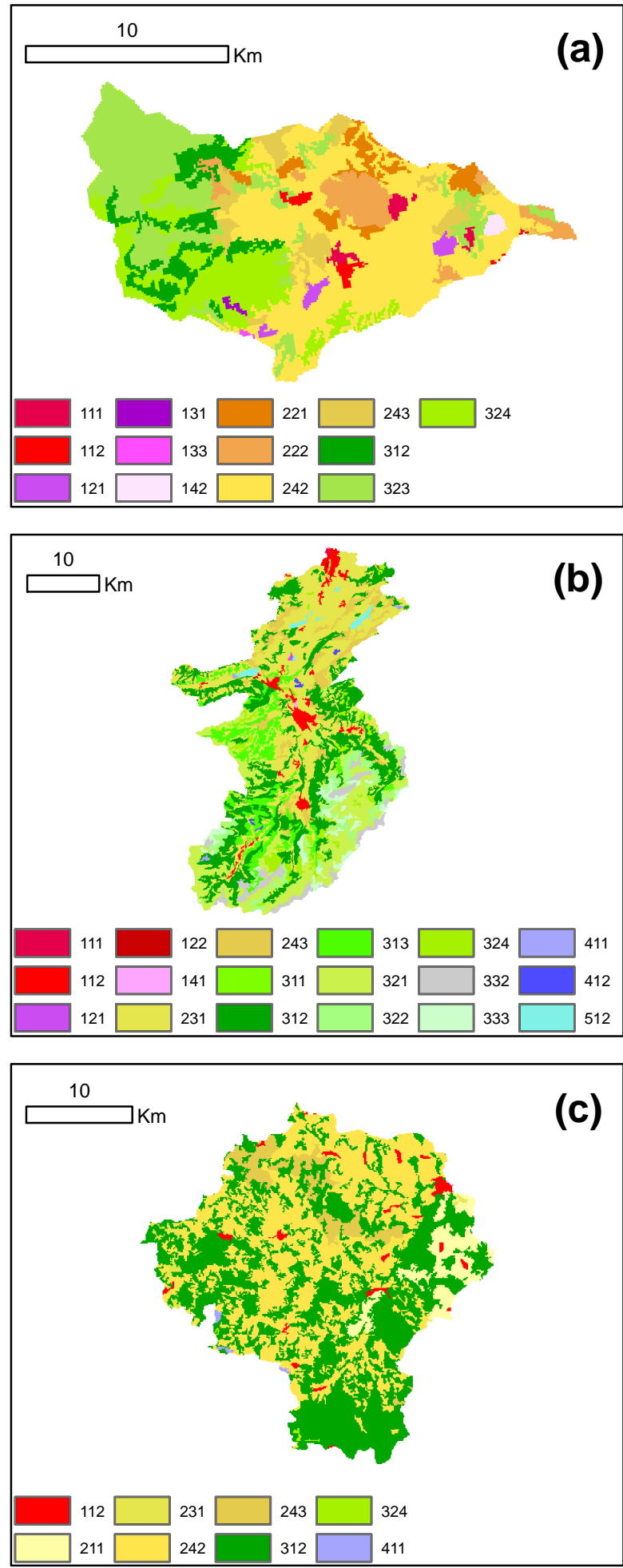

\section{Legend}

Code Land cover class description (LABEL3)

111 Continuous urban fabric

112 Discontinuous urban fabric

121 Industrial or commercial units

122 Road and rail networks and

associated land

131 Mineral extraction sites

133 Construction sites

141 Green urban areas

142 Sport and leisure facilities

211 Non-irrigated arable land

221 Vineyards

222 Fruit trees and berry plantations

231 Pastures

242 Complex cultivation patterns

243 Land principally occupied by

$$
\begin{aligned}
& \text { agriculture, with significant } \\
& \text { areas of natural vegetation }
\end{aligned}
$$

311 Broad-leaved forest

312 Coniferous forest

313 Mixed forest

321 Natural grasslands

322 Moors and heathland

323 Sclerophyllous vegetation

324 Transitional woodland-shrub

332 Bare rocks

333 Sparsely vegetated areas

411 Inland marshes

412 Peat bogs

512 Water bodies

Fig. 4. CLC2000 classes (Source: European Environment Agency) obtained for the catchments: (a) Poyo, (b) Upper Iller and (c) Kamp. The direction of land cover changes for the afforestation scenarios are as follows: from codes 242 (complex cultivation patterns) at Poyo and Kamp and 231 (pastures) at Upper Iller to code 312 (coniferous forest). 
Table 1. Main characteristics of the study areas.

\begin{tabular}{llll}
\hline Name of the Catchment & Poyo & Upper Iller & Kamp \\
\hline $\begin{array}{l}\text { Hydro-climatological } \\
\text { region }\end{array}$ & Mediterranean & Alpine & Continental \\
\hline $\begin{array}{l}\text { Mean annual } \\
\text { precipitation } \\
\left(\mathrm{mm} \mathrm{yr}^{-1}\right)\end{array}$ & 450 & 2000 & 900 \\
\hline $\begin{array}{l}\text { Mean runoff } \\
\text { coefficient }(\%)\end{array}$ & $\begin{array}{l}2 \text { (annual); } \\
8 \text { (event-based) }\end{array}$ & 78 (annual) & 33 (annual) \\
\hline $\begin{array}{l}\text { The flood- } \\
\text { producing } \\
\text { rainfall }\end{array}$ & Convective rainstorms & $\begin{array}{l}\text { Heavy orographic } \\
\text { rainfall }\end{array}$ & $\begin{array}{l}\text { Synoptic events, } \\
\text { convective } \\
\text { storms and rain } \\
\text { on snow }\end{array}$ \\
\hline $\begin{array}{l}\text { Main flood } \\
\text { typologies }\end{array}$ & Flash floods & Largest floods & $\begin{array}{l}\text { Largest floods, } \\
\text { flash floods, } \\
\text { snow melt floods }\end{array}$ \\
\hline $\begin{array}{l}\text { Drainage area } \\
\left.\text { (km }{ }^{2}\right)\end{array}$ & 184 & & 621 \\
\hline $\begin{array}{l}\text { Range of } \\
\text { altitude } \\
(\mathrm{m} \text { a.s.l.) }\end{array}$ & $111-1030$ & 954 & $500-996$ \\
\hline \begin{tabular}{l} 
Mean slope $(\%)$ \\
\hline
\end{tabular} & 12.3 & $658-2638$ & 6 \\
\hline
\end{tabular}

Table 2. Summary of available data for each catchment model.

\begin{tabular}{|c|c|c|c|}
\hline Input data & TETIS/Poyo & $\begin{array}{l}\text { MODEL/Catchment } \\
\text { WASIM-ETH/Upper } \\
\text { Iller }\end{array}$ & KAMPUS/Kamp \\
\hline \multicolumn{4}{|l|}{ Spatial data } \\
\hline Digital Elevation Model & $100 \mathrm{~m}$ grid size & $50 \mathrm{~m}$ grid size & $1000 \mathrm{~m}$ grid size \\
\hline Land cover & $\begin{array}{l}\text { Land cover map of the } \\
\text { Valencia region, } 1998 \\
\text { version }(1: 25000)\end{array}$ & $\begin{array}{l}\text { CORINE Land Cover } \\
2000(1: 100000)\end{array}$ & $\begin{array}{l}\text { Landsat image } \\
(1 \mathrm{~km} \times 1 \mathrm{~km})\end{array}$ \\
\hline Soils & $\begin{array}{l}\text { Soil map of Spain, } \\
\text { Valencia region } \\
(1: 1000000)\end{array}$ & $\begin{array}{l}\text { Soil map of } \\
\text { Germany-BÜK1000- } \\
(1: 1000000)\end{array}$ & $\begin{array}{l}\text { Digital soil map of Aus- } \\
\text { tria }(1: 25000)\end{array}$ \\
\hline Geology & $\begin{array}{l}\text { Geological map of } \\
\text { Spain }(1: 50000)\end{array}$ & $\begin{array}{l}\text { Geological map of } \\
\text { Germany-GK1000- } \\
(1: 1000000)\end{array}$ & $\begin{array}{l}\text { Geological map sheets } \\
\text { of Austria (1:50000) }\end{array}$ \\
\hline Hydro-meteorological data & Period (1988-2007) & Period (2002-2005) & Period (1993-2005) \\
\hline Precipitation & $\begin{array}{l}1 \text { rain gauge at } 5-\mathrm{min} \\
\text { resolution }\end{array}$ & $\begin{array}{l}11 \text { rain gauges at hourly } \\
\text { resolution }\end{array}$ & $\begin{array}{l}10 \text { rain gauges at } \\
15 \text {-min and } 6 \text { rain } \\
\text { gauges at daily } \\
\text { resolutions }\end{array}$ \\
\hline Air temperature & $\begin{array}{l}2 \text { stations at } 5 \mathrm{~min} \\
\text { resolution }\end{array}$ & $\begin{array}{l}7 \text { stations at hourly } \\
\text { resolution }\end{array}$ & $\begin{array}{l}8 \text { station at } \\
15 \text {-min resolution }\end{array}$ \\
\hline Runoff & $\begin{array}{l}1 \text { runoff gauge at } 5 \text {-min } \\
\text { resolution }\end{array}$ & $\begin{array}{l}8 \text { runoff gauges at } \\
\text { hourly } \\
\text { resolution }\end{array}$ & $\begin{array}{l}1 \text { runoff gauge at } \\
15 \text {-min resolution }\end{array}$ \\
\hline
\end{tabular}


volumes. Other flood processes are flash floods driven by convective storms that occur at smaller spatial scales and which can lead to a very rapid rise in the flood stages. Still other flood types are snow melt floods and rain on snow floods that may occur in winter or spring which are typically associated with gradual rises of stream water levels. A number of floods have been recorded in this catchment, with the most important and exceptional event taking place in August 2002, which caused significant damage to the catchment.

\section{Hydrological models}

Three process-oriented distributed rainfall-runoff models specifically tailored and adapted for the peculiarities of the different catchments and their hydro-climatic settings, were applied and compared in this study. Under the current conditions pertaining to each study area, the methodology involved: (i) the identification of the model structure and its respective parameters, including the possibility of a model calibration; and (ii) a model evaluation using the recorded historical events not used in calibration, following the considerations given by Klemeš (1986). Therefore, it is necessary to bear in mind that the process-oriented hydrological modelling in this framework is for planning purposes, decision-making support and performance is judged with historical observations. In this sense, the model evaluation is to demonstrate that physical dominant processes in the basin have been simulated appropriately and the model is capable of performing projections based on the characteristics prevailing in the catchment for the reference period. Model evaluation methods such as quantitative statistics and graphical techniques were used in this stage according to standard recommendations (e.g., Moriasi et al., 2007). On this basis, the proposed flood management measures were analysed by means of changes in the model parameters based on the current physical characteristics identified previously. Subsequent simulations using the same recorded historical event were realised with this new set of altered parameters. The results of this analysis were the hydrographs for both current conditions and each scenario which allowed us to compare the effectiveness of each measure on flood magnitude in terms of peak discharge reduction.

The three catchment models applied and compared in this study are: TETIS model (Francés et al., 2007) for the Poyo catchment, WASIM-ETH version 1 (Schulla and Jasper, 2007) for the Upper Iller catchment and KAMPUS model (Blöschl et al., 2008) for the Kamp catchment. Each model has been successfully used for different model-based applications in similar hydro-climatic regions. For example, the TETIS model was performed for a regional water resources study in the Basque Country Region, northern Spain (Vélez et al., 2009), the WASIM-ETH was applied in SW Germany to analyse the impact of land-use change impacts on stormrunoff generation (Niehoff et al., 2002), while the KAMPUS model is in operational use for forecasting flash floods in northern Austria (Blöschl et al., 2008).

TETIS, WASIM-ETH and KAMPUS have two important common characteristics: they are distributed in cells and their parameters have a physical meaning. They require two kinds of input data (see Table 2): a physical characterisation of the study area (topography, land cover, soils, geology) to build a set of spatial parameters, and a hydro-meteorological time series for parameter identification, model evaluation and simulations. As can be seen in Table 2, spatial data from different resolutions were obtained in each case study. With the help of geographic information systems it is possible to use the spatial data from different resolutions and combine them. Based on these pre-processed data, grid cell sizes were established as follows: $50 \mathrm{~m}$ at Upper Iller, $100 \mathrm{~m}$ at Poyo and $1000 \mathrm{~m}$ at Kamp. Time steps were equal to $5 \mathrm{~min}$ at Poyo, $15 \mathrm{~min}$ at Kamp and $60 \mathrm{~min}$ at Upper Iller. On the other hand, the models differ in the conceptualization for the hydrological processes. The main hydrological processes represented by them are summarised in Table 3, while a brief description is presented as follows. In the TETIS model, runoff generation processes at each cell is based on linked storages, each one representing the different water storages in an "extended soil column", while runoff routing of the flow components (overland, interflow and baseflow) collected by the drainage network is performed using the so called "Geomorphological Kinematic Wave" approach (Francés et al., 2007). The WASIM-ETH model is grid-based in the calculation of evapotranspiration, interception, snow melt and snow storage, infiltration and vertical soil water movement. It emphasises runoff generation by explicitly accounting for processes like infiltration, macropore flows, infiltration excess and saturation excess. The overland, interflow and baseflow are simulated as linear storages, with the former two being calculated per grid cell, while baseflow is calculated on the basis of the entire subcatchments ( 8 in the case of Upper Iller). For streamflow routing, the "Kinematic Wave" approach is used. The Kamp catchment at Zwettl was divided into three subcatchments with two river reaches. In the KAMPUS model, the processes which are represented at grid scale are snow, soil moisture and hillslope scale routing. In addition, a transfer function is used to represent the runoff routing in the streams within the subcatchment and stream routing processes are formulated at the reach scale using a lumped routing model.

The next step in this modelling approach was the proper identification of model parameters. The TETIS model, implemented in the Poyo catchment, organises each effective parameter following a split structure (Francés et al., 2007), consisting in a prior estimated map at pixel scale (grid element) based on spatial data listed in Table 2, and a common correction factor for each parameter. The correction factors take into account input and model errors as well as spatiotemporal scale effects. In order to obtain an optimal set of correction factors, TETIS is coupled with an automatic 
Table 3. Main process descriptions of each catchment model.

\begin{tabular}{|c|c|c|c|}
\hline & TETIS/Poyo & WASIM-ETH/Upper Iller & KAMPUS/Kamp \\
\hline \multicolumn{4}{|l|}{ Runoff generation } \\
\hline Snow melt & - & Degree day method & Degree day method \\
\hline Actual evapotranspiration & $\begin{array}{l}\text { Reduction function of poten- } \\
\text { tial evapotranspiration based on } \\
\text { land cover and upper soil mois- } \\
\text { ture content }\end{array}$ & $\begin{array}{l}\text { Reduction function of poten- } \\
\text { tial evapotranspiration based on } \\
\text { soil moisture storage }\end{array}$ & $\begin{array}{l}\text { Reduction function of potential } \\
\text { evaporation based on the soil } \\
\text { moisture of the top layer }\end{array}$ \\
\hline Interception & $\begin{array}{l}\text { Storage capacity depending on } \\
\text { leaf biomass and vegetation } \\
\text { type }\end{array}$ & $\begin{array}{l}\text { Storage capacity depending on } \\
\text { the leaf area index, the vege- } \\
\text { tation coverage degree, and the } \\
\text { maximum height of water at the } \\
\text { leafs }\end{array}$ & $\begin{array}{l}\text { Storage-based approach: Linear } \\
\text { equation }\end{array}$ \\
\hline Infiltration & $\begin{array}{l}\text { Function based on upper soil } \\
\text { saturated hydraulic conductiv- } \\
\text { ity }\end{array}$ & $\begin{array}{l}\text { Function based on the GREEN } \\
\text { and AMPT approach }\end{array}$ & $\begin{array}{l}\text { Storage-based approach: Linear } \\
\text { equation }\end{array}$ \\
\hline Percolation & $\begin{array}{l}\text { Function based on saturated hy- } \\
\text { draulic conductivity of the deep } \\
\text { soil or base rock }\end{array}$ & $\begin{array}{l}\text { Exponential function based on } \\
\text { soil saturation deficit and satu- } \\
\text { rated hydraulic conductivity }\end{array}$ & $\begin{array}{l}\text { Storage-based approach: Linear } \\
\text { equation }\end{array}$ \\
\hline Overland flow & $\begin{array}{l}\text { Storage-based approach: Linear } \\
\text { equation taking into account } \\
\text { the hillslope surface velocity }\end{array}$ & $\begin{array}{l}\text { Sum of all possible three com- } \\
\text { ponents: from snow melt, from } \\
\text { infiltration excess and from sat- } \\
\text { urated areas }\end{array}$ & $\begin{array}{l}\text { Storage-based approach: Linear } \\
\text { equation }\end{array}$ \\
\hline Interflow & $\begin{array}{l}\text { Storage-based approach: Linear } \\
\text { equation taking into account the } \\
\text { horizontal hydraulic conductiv- } \\
\text { ity of the upper part of the soil }\end{array}$ & $\begin{array}{l}\text { Function based on the soil satu- } \\
\text { ration deficit which is based on } \\
\text { the topographic index }\end{array}$ & $\begin{array}{l}\text { Storage-based approach: Linear } \\
\text { equation }\end{array}$ \\
\hline Baseflow & $\begin{array}{l}\text { Storage-based approach: Linear } \\
\text { equation taking into account the } \\
\text { aquifer saturated hydraulic con- } \\
\text { ductivity }\end{array}$ & $\begin{array}{l}\text { Exponential function. It is gen- } \\
\text { erated for an entire subcatch- } \\
\text { ment as average value }\end{array}$ & $\begin{array}{l}\text { Storage-based approach: Linear } \\
\text { equations. There are two com- } \\
\text { ponents: from the lower soil } \\
\text { zone and groundwater flow }\end{array}$ \\
\hline \multicolumn{4}{|l|}{ Runoff routing } \\
\hline Within-catchment routing & Linear storage-based approach & Linear storage-based approach & Linear storage-based approach \\
\hline Stream routing & $\begin{array}{l}\text { Geomorphological Kinematic } \\
\text { Wave }\end{array}$ & Kinematic Wave & Linear storage-based approach \\
\hline
\end{tabular}

optimisation algorithm based on the SCE-UA method (Duan et al., 1994). In the Upper Iller catchment, this stage was carried out with WASIM-ETH model, involving a combination of two procedures: the first one involving a initial parameter estimate using a long list of parameter sets (100200) based on spatial data listed in Table 2, and the second one based on the freely available PEST software for nonlinear parameter optimisation, using the Gauss-MarquardtLevenberg algorithm (Doherty, 2005). The calibration comprised only the 10 most relevant model parameters related to runoff generation. In the Kamp catchment, the strategy used with KAMPUS model was based on the "multi-source model identification" and on the "dominant processes concept" of
Grayson and Blöschl (2000). Grayson and Blöschl (2000) suggest that, the development, calibration and testing of distributed models should ideally involve observed spatial patterns of catchment response which can come from a number of sources, and that, at different locations and different points in time, a small number of processes will dominate over the rest. To this end, Hydrological Response Units (HRUs) were defined manually rather than by overlaying the spatial data listed in Table 2, allowing some interpretation of the understanding of the hydrology of the area to be introduced. Table 4 summarises a brief description of the main model parameters identified in each case study, while a detailed description of model structure as well as all model parameters 
Table 4. Summary of the main model parameters identified at each case study.

\begin{tabular}{|c|c|c|c|}
\hline MODEL/Catchment & Parameter & Description & Unit \\
\hline \multirow{7}{*}{ TETIS/Poyo } & $\mathrm{Hu}$ & Maximum static storage & $\mathrm{mm}$ \\
\hline & $\lambda(\mathrm{m})$ & Vegetation cover index for month & - \\
\hline & $\mathrm{k}_{\mathrm{s}}$ & Infiltration capacity & $\mathrm{cm} \mathrm{h}^{-1}$ \\
\hline & $\mathrm{u}$ & Overland runoff velocity & $\mathrm{m} \mathrm{s}^{-1}$ \\
\hline & $\mathrm{k}_{\mathrm{p}}$ & Percolation capacity & $\mathrm{cm} \mathrm{h}^{-1}$ \\
\hline & kss & Interflow velocity & $\mathrm{cm} \mathrm{h}^{-1}$ \\
\hline & $\mathrm{v}$ & Channel velocity & $\mathrm{m} \mathrm{s}^{-1}$ \\
\hline \multirow{10}{*}{ WASIM-ETH/Upper Iller } & $\mathrm{m}$ & Recession parameter for baseflow & $\mathrm{m}$ \\
\hline & $\mathrm{T}_{\text {corr }}$ & Correction factor for soil transmissivity & - \\
\hline & $\mathrm{K}_{\mathrm{corr}}$ & Correction factor for vertical percolation & - \\
\hline & $\mathrm{kD}$ & Single reservoir recession const.-surface runoff & $\mathrm{h}$ \\
\hline & $\mathrm{H}_{\max }$ & Maximum storage capacity of interflow storage & $\mathrm{mm}$ \\
\hline & $\mathrm{kH}$ & Single reservoir recession const.-interflow & $\mathrm{h}$ \\
\hline & t0r & Temperature limit for rain & $\mathrm{C}$ \\
\hline & to & Temperature limit for snow melt & $\mathrm{C}$ \\
\hline & $\mathrm{c} 0$ & Degree-day-factor & $\mathrm{mmdC}^{-1}$ \\
\hline & $\mathrm{c}_{\text {melt }}$ & Fraction of snowmelt which is surface runoff & - \\
\hline \multirow{7}{*}{ KAMPUS/Kamp } & $\mathrm{D}$ & Melt factor & $\mathrm{mmdk}$ \\
\hline & $\mathrm{L}_{\mathrm{p}}$ & Limit for potential evaporation & $\mathrm{mm}$ \\
\hline & $\mathrm{L}_{\mathrm{S}}$ & Maximum soil moisture storage & $\mathrm{mm}$ \\
\hline & $\beta$ & Nonlinearity parameter which controls the characteristics of runoff generation & \\
\hline & L1 & Threshold value for surface runoff generation & $\mathrm{mm}$ \\
\hline & $\mathrm{L}_{\mathrm{cp}}$ & Maximum percolation rate & $\mathrm{mm} \mathrm{d}^{-1}$ \\
\hline & $\mathrm{L}_{\text {by }}$ & Maximum percolation rate to the storage of the lower soil zone & $\mathrm{mm} \mathrm{d}^{-1}$ \\
\hline
\end{tabular}

Table 5. Parameters altered by the afforestation scenario.

\begin{tabular}{|c|c|c|c|c|c|c|c|c|c|}
\hline \multirow{2}{*}{$\begin{array}{l}\text { MODEL/ } \\
\text { Catchment }\end{array}$} & \multirow{2}{*}{$\begin{array}{l}\text { Area } \\
\left(\mathrm{km}^{2}\right)\end{array}$} & \multicolumn{2}{|c|}{ Forest cover $(\%)$} & \multirow[t]{2}{*}{ Altered parameter } & \multicolumn{2}{|c|}{ Cell value } & \multicolumn{2}{|c|}{ Areal storage value $(\mathrm{mm})$} & \multirow[t]{2}{*}{ MAISC (mm) } \\
\hline & & Current & Affor. & & Current & Affor. & Current & Affor. & \\
\hline \multirow[t]{4}{*}{ TETIS/Poyo } & 184 & 1 & 28 & Upper soil capillary capacity (mm) & 24-91 & $29-98$ & 107 & 111 & 4 \\
\hline & & & & Detention in puddles $(\mathrm{mm})$ & 15 & 17 & & & \\
\hline & & & & Interception (mm) & 3 & 9 & & & \\
\hline & & & & Vegetation cover index & $0.2-0.6$ & 1 & & & \\
\hline \multirow{2}{*}{$\begin{array}{l}\text { WASIM- } \\
\text { ETH/Upper } \\
\text { Iller }\end{array}$} & 954 & 32 & 65 & Plant parameters & 2.1 & 2.7 & 33.7 & 36.9 & 3.2 \\
\hline & & & & Storage capacity of soil (mm) & 100 & 109 & & & \\
\hline \multirow{3}{*}{$\begin{array}{l}\text { KAMPUS/ } \\
\text { Kamp* }\end{array}$} & 621 & $14 / 33$ & $23 / 63$ & Storage capacity of soil (mm) & $90 / 180$ & $110 / 200$ & $8.1 / 54$ & $9.9 / 60$ & 7.8 \\
\hline & & & & Nonlinearity parameter & $2 / 3$ & $3 / 5$ & & & \\
\hline & & & & Threshold for overland flow (mm) & $8 / 50$ & $15 / 50$ & & & \\
\hline
\end{tabular}

* Distinction made between steep slopes/hills.

can be seen in the references given above (i.e., Francés et al., 2007; Schulla and Jasper, 2007; and Blöschl et al., 2008, respectively).

\section{Flood management scenarios and its parameterisation}

The flood management measures studied in this paper (afforestation, micro-ponds and small-reservoirs) are based on the "retaining water in the landscape" concept, all of them producing a higher retention capacity within the catchment, but in different ways. Afforestation has been proposed as one of the most popular land-use changes for runoff generation reduction. On the other hand, micro-ponds and small- reservoirs have been suggested as two kinds of measures that focus on the introduction of small retention elements in the landscape forming small wetland areas. Here, the distinction between micro-pond and small-reservoir lies in the location of these small retention elements: while micro-ponds are located on hillslopes, small-reservoirs are situated within the channel network. These measures are introduced in each catchment model to compare their similarities and differences.

In order to have a standardised measurement of the implications of different scenarios and catchment sizes, a novel index, namely, the "Mean Areal Increase of Storage Capacity" (MAISC) has been introduced in this work. As can be seen in Eq. (1), the MAISC index is the difference between current condition and future scenarios in the relation between 
storage capacity of water retention and catchment area.

MAISC $=\left(\frac{\mathrm{S}_{\mathrm{i}}-\mathrm{S}_{0}}{A}\right)$

where $S_{0}$ is the current catchment storage capacity, $S_{i}$ is the future scenario catchment storage capacity and $A$ is the catchment area.

\subsection{Afforestation}

For the Poyo catchment, afforestation was proposed as a way of ecological restoration on current agricultural areas (mainly complex cultivation patterns). Based on this criterion, the forest cover can be increased from $1 \%$ to $28 \%$. In the Upper Iller catchment, the potential areas for afforestation were chosen in the following way: (i) afforestation areas were only derived from land characterised as pastures below the tree line; (ii) only pastures with a gradient of more than $5 \%$ were chosen, as this area is characterised by a steep topography and the more level terrain was the more valuable to farmers; and iii) plots had to be greater than $5000 \mathrm{~m}^{2}$. The resulting forested area totalled $620 \mathrm{~km}^{2}$, corresponding to an increase from $32 \%$ to $65 \%$ of the whole catchment area. In the Kamp catchment, agricultural areas (mainly complex cultivation patterns) were assumed to be planted with pine trees, but making a distinction between hills and steep slopes to take into account their differences in the runoff generation: steep slopes are characterised by a lower soil storage capacity and faster runoff response. In the end, forest area was increased from $14 \%$ to $23 \%$ on steep slopes, and from $33 \%$ to $63 \%$ on hills. Percentages of afforestation scenario compared to the current conditions are given in Table 5. Figure 4 specifies the current land cover which is to be converted to forest cover.

Modelling the impacts of afforestation and/or other landuse or vegetation changes has the major challenge of reflecting the nature of changes in model parameter values, given an associated uncertainty in the modelling of discharges under current conditions (Beven, 2001). According to Bronstert et al. (2007), the effects of land-use changes on runoff processes can be estimated by establishing a relationship between the model parameters and the land use characteristics of the catchment. Niehoff et al. (2002) suggest taking into account the following runoff generation issues: (i) the role of land-cover and soil characteristics in infiltration processes; (ii) the role of initial soil moisture conditions before flood events and (iii) the spatiotemporal dynamic of rainfall events. In this study, we have assumed changes in the soil structure, keeping in mind the actual characteristics of present forest soils. We expect an increase in processes such as interception and infiltration rates in forested areas, with a concomitant reduction in surface runoff and flood response (Calder and Aylward, 2006; Jewitt, 2005). The forest hydrology recognises that soil properties can change in two different ways in the mid- and long-term: (i) changes due to forest management that will tend to revert to the antecedent conditions before the disturbance; and (ii) changes due to the growth of trees and their effects on soil properties, causing an increase in soil storage capacity. In this sense, changes in model parameterisation have been made by taking into account changes in the soil and vegetation properties defined for each model structure.

Table 5 shows a summary of the modified parameters by the afforestation scenario for each catchment model. A brief explanation of the changes made to each hydrological model is presented as follows. In the Poyo catchment model, the TETIS model maximum static storage parameter $(\mathrm{Hu})$ was changed by increasing its components: the capillary water storage in the upper part of the soil (by a range of 5-7 mm) and the initial abstractions $(6 \mathrm{~mm}$ for interception and $2 \mathrm{~mm}$ for puddles). These increments were established by comparing the values of the existing forest (mainly pine) and agricultural areas at pixel scale. This increase in Hu represents a MAISC equal to $4 \mathrm{~mm}$. Also, the vegetation cover index (which takes part in the actual evapotranspiration estimation) was increased from $0.2-0.6$ in current area to 1 for the new pine forest. In the Upper Iller catchment, an increase in forested area directly affects interception, evaporation and transpiration via the WASIM-ETH plant parameters (LAI, root depth, canopy resistance to wind, and albedo). This meant an increase in areal maximum interception storage from $2.1 \mathrm{~mm}$ to $2.7 \mathrm{~mm}$. Additionally, there was an increase in soil storage capacity by $2 \%$. The final MAISC was about $3.2 \mathrm{~mm}$. In the Kamp catchment, the KAMPUS model parameters were changed as follows: the overland runoff is mainly influenced by the maximum soil moisture storage (called Ls) and parameter $\beta$, which accounts for the nonlinearity of runoff generation processes; the occurrence of surface runoff depends on the threshold value (called L1), which defines the storage level at which the capacity of the upper soil layer is exhausted and the overflow of the reservoir begins. The greater capacity to retain water in the forested areas was represented by a greater storage capacity L1 of the soils ( $20 \mathrm{~mm}$ greater than that of non-forested areas). The nonlinearity parameter $\beta$ was set to a value of $\beta=3$ for forested slopes and $\beta=5$ for forested hills. For non-forested areas, the less distinctive nonlinearity of runoff processes was represented by lower $\beta$ for the slopes $(\beta=2)$ and hills $(\beta=2)$. The threshold parameter L1 for the occurrence of surface runoff was set to $15 \mathrm{~mm}$ for forested slopes and $7 \mathrm{~mm}$ for non-forested slopes. Surface runoff rarely occurs in the hills with moderate slopes, therefore, no difference was made between parameter L1 for forested and non-forested hills. In both cases, threshold L1 was set to $50 \mathrm{~mm}$. Consequently, for this scenario, MAISC was found to be about $7.8 \mathrm{~mm}$. 
Table 6. Parameters to be considered in the analysis of the retention elements in the landscape scenarios (current storage capacity is null).

\begin{tabular}{|c|c|c|c|c|c|}
\hline $\begin{array}{l}\text { MODEL/ } \\
\text { Catchment }\end{array}$ & Scenario & $\begin{array}{l}\text { Retention } \\
\text { capacity }\left(\mathrm{m}^{3}\right)\end{array}$ & Parameter & Pixel value & MAISC (mm) \\
\hline TETIS/Poyo* & $\begin{array}{l}\text { Small- } \\
\text { reservoirs }\end{array}$ & $85887 / 220195$ & $\begin{array}{l}\text { Stage-volume }\left(m-m^{3}\right) \text { and rating curves } \\
\left(m-m^{3} s^{-1}\right)\end{array}$ & not applicable & $0.47 / 1.2$ \\
\hline \multirow[t]{2}{*}{$\begin{array}{l}\text { WASIM- } \\
\text { ETH/Upper } \\
\text { Iller }\end{array}$} & $\begin{array}{l}\text { Small- } \\
\text { reservoirs }\end{array}$ & 452000 & $\begin{array}{l}\text { Fixed volume }\left(\mathrm{m}^{3}\right) \text {, fraction of overland } \\
\text { flow routed into them and constant out- } \\
\text { flow }\left(\mathrm{m}^{3} \mathrm{~s}^{-1}\right)\end{array}$ & not applicable & 0.47 \\
\hline & Micro-ponds & 1144800 & $\begin{array}{l}\text { Surface retention (mm) } \\
\text { Hydraulic conductivity }\left(\mathrm{m} \mathrm{s}^{-1}\right)\end{array}$ & $\begin{array}{l}1.2 \\
1 \times 10^{-8}\end{array}$ & 1.2 \\
\hline KAMPUS/Kamp & Micro-ponds & 750000 & $\begin{array}{l}\alpha \mathrm{M} \\
\mathrm{LM}(\mathrm{mm}) \\
\operatorname{percM}\left(\mathrm{mmd}^{-1}\right)\end{array}$ & $\begin{array}{l}0.4 \\
3 \\
1\end{array}$ & 1.2 \\
\hline
\end{tabular}

* In Poyo catchment there are two small-reservoir scenarios (see text for more explanations.)

\subsection{Retention elements in the landscape: small-reservoirs and micro-ponds}

A set of small dams (to produce small-reservoirs) for the channel network was proposed for both Poyo and Upper Iller catchments. An example of the spatial distribution of these retention elements can be seen in Fig. 5. For Poyo, this scenario was based on a technical proposal for flood control prepared by the Jucar River Basin Authority which proposed 184 reservoirs in the headwater catchment area with a total storage of 16 million cubic metres. These reservoirs include dams of different sizes (ranging from 5 to $30 \mathrm{~m}$ ), with similar spillway characteristics and none of them possesses a bottom outlet. Based on this realistic scenario, we have generated two scenarios with dams lower than $10 \mathrm{~m}$ and seeking the same MAISC used in the other study areas (as it is described below); i.e., a MAISC equal to $0.47 \mathrm{~mm}$ for the small-reservoir scenario in the Upper Iller catchment and a MAISC equal to $1.2 \mathrm{~mm}$ for the micro-pond scenarios in both the Upper Iller and Kamp catchments. As a result, there was one scenario with three five-metre high dams, and nine ten-metre high dams. Its volume retention ranges between 432 to $41725 \mathrm{~m}^{3}$, with a total water storage capacity of about $85887 \mathrm{~m}^{3}$ inundating a catchment area of about $0.02 \%\left(0.04 \mathrm{~km}^{2}\right)$. The other scenario has three five-metre high dams and 34 ten-metre dams. It has a potential water storage capacity of about $220195 \mathrm{~m}^{3}$, with a inundated area in the catchment of about $0.05 \%\left(0.09 \mathrm{~km}^{2}\right)$. The Modified Puls Method (see e.g., Ponce, 1989) was used to represent the runoff routing at each small-reservoir. In the Upper Iller catchment, the potential locations and volume of the smallreservoirs were determined during a field campaign in May 2007. The selection of locations was based on the local microtopography. The reservoirs are thought to be restricted by a small dam (maximum height $5 \mathrm{~m}$ ) with a culvert. These small-reservoirs are characterised by the fraction of overland

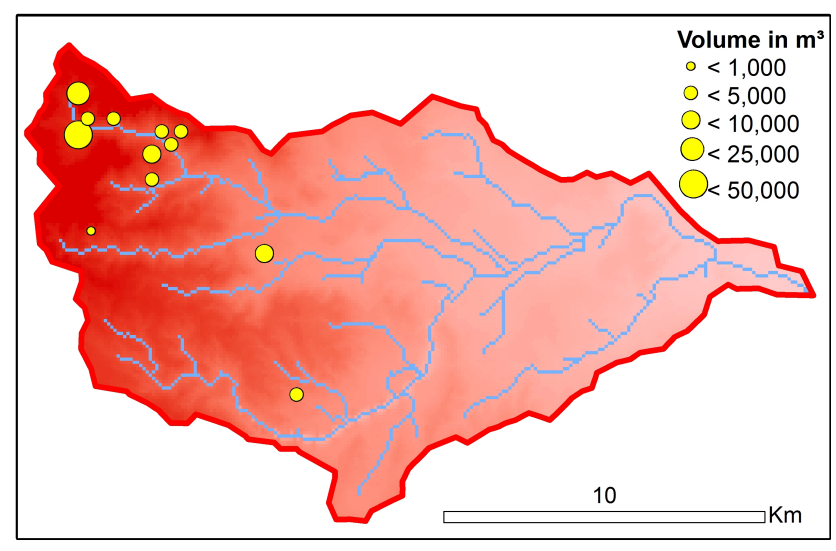

Fig. 5. Small-reservoir scenario for the Poyo catchment (MAISC $=0.47 \mathrm{~mm})$.

flow routed into them or their inflows (defined by the ratio of catchment size of the reservoir over the size of the subcatchment), a constant outflow and a fixed volume from 1000 to $100000 \mathrm{~m}^{3}$. Summing up all values over the entire catchment, a retention volume of $452000 \mathrm{~m}^{3}$ can be obtained and an accumulated reservoir catchment area of $90.3 \mathrm{~km}^{2}(9.5 \%$ of the whole area). This scenario is equivalent to a MAISC about $0.47 \mathrm{~mm}$.

A set of micro-ponds were also proposed for both Upper Iller and Kamp catchments. The basic principle of this scenario is to retain a fraction of the surface runoff on the hillslope by small dams, which would also affect downhill soil moisture. Figure 6 shows examples of feasible locations for these retention elements. In the Upper Iller catchment this scenario was implemented by increasing the potential of surface retention by $1.2 \mathrm{~mm}$. This storage can only be filled by infiltration excess overland flow or saturation excess overland flow. Once neither saturation excess nor infiltration access are generated any longer (e.g., after the rainfall event or 

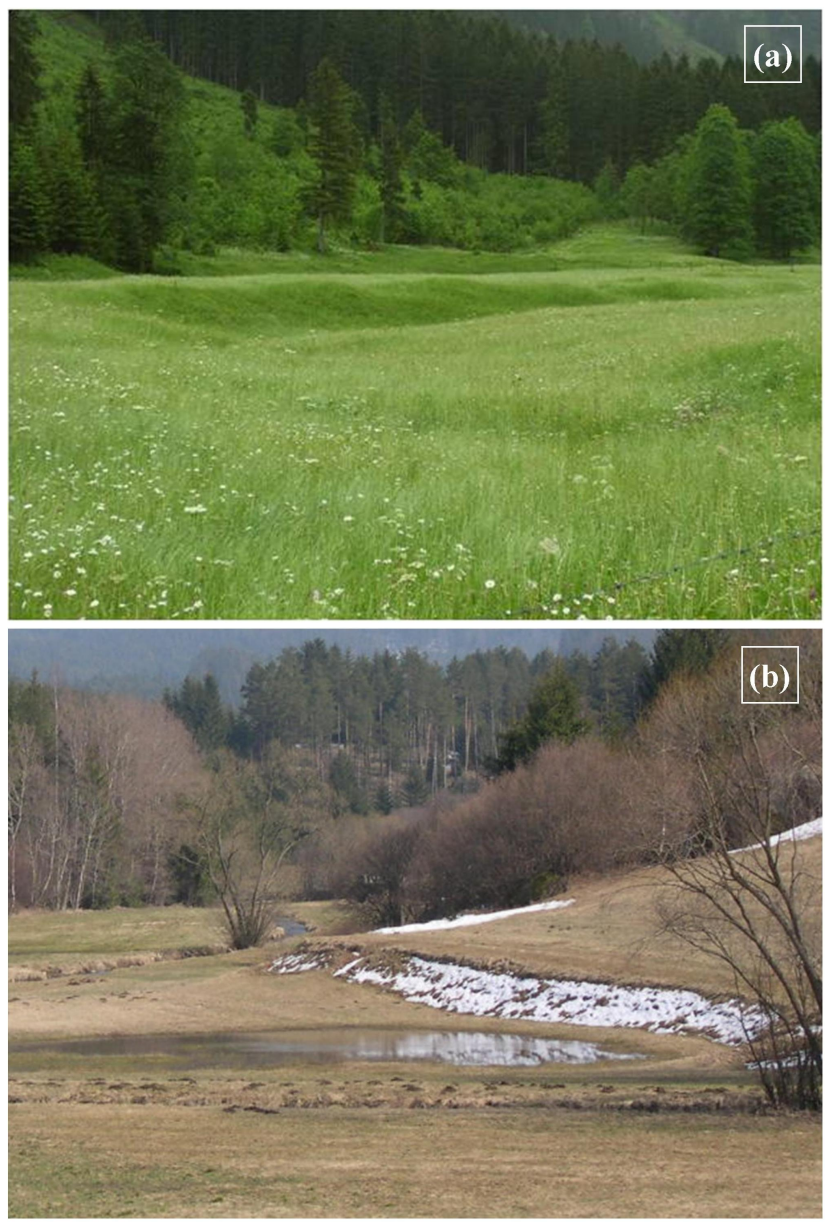

Fig. 6. Examples of feasible locations for micro-ponds in the catchments: (a) Upper Iller and (b) Kamp.

at lesser rainfall intensities) the storage is emptied by infiltration. This results in a potential capacity of water retention of about $1144800 \mathrm{~m}^{3}$ and a MAISC of about $1.2 \mathrm{~mm}$. However, as these water-filled soil hollows are likely to cause sedimentation of fines on the soil surface, the hydraulic conductivity assumed for infiltration was reduced to $1 \times 10^{-8} \mathrm{~m} \mathrm{~s}^{-1}$. In the Kamp catchment, the volume of each micro-pond was of the order of $100 \mathrm{~m}^{3}$, with a total capacity for water retention of about $750000 \mathrm{~m}^{3}$ (7500 micro-ponds or 12 micro-ponds per $\mathrm{km}^{2}$ ), giving a MAISC value of about $1.2 \mathrm{~mm}$. Some modifications were made to the KAMPUS model structure of the Kamp catchment in order to represent the additional water retention of the micro-ponds. These elements were represented by additional bucket storages with a fixed spill-over. The micro-ponds were only drained by constant deep percolation to ground water storage. The drained water from the micro-ponds contributes to runoff with a certain delay in time and, hence, does not contribute to the fast runoff processes during the rising limb of floods. This is because of the very slow ground water processes. The modification of the hydrologic model accounts for these micro-ponds in the catchment results with the addition of three model parameters: the areal fraction of the grid elements drained into micro-ponds $(\alpha \mathrm{M})$, the threshold for limiting the storage capacity of the bucket (LM) and the constant deep percolation rate (percM) for drainage of the bucket storage. The parameters were set as lumped values for the entire catchment. Full bucket storage $(3 \mathrm{~mm})$ empties within a dry period of three days and the full retention capability of the bucket storage is recovered. For each pixel element $\left(1 \mathrm{~km}^{2}\right)$ an additional storage capacity was obtained by multiplying this value with the other parameters (i.e., $\alpha \mathrm{M} \times \mathrm{LM} \times$ percM).

As can be explained above, the scenarios described were introduced in each hydrological model either by changing model parameters or by using new parameters in the reservoir routing. Table 6 shows a summary of the new retention capacity in each catchment model and the model parameters introduced with these measures and their values.

\section{Results and discussion}

\subsection{Modelling the current conditions}

There are only relatively few hydro-meteorological data for the Poyo catchment, with only one rain gauge and one flow gauge providing observations every $5 \mathrm{~min}$, which are operated by the Real Time System of Hydrological Information of the Jucar River Basin Authority. Since the late 1980s (when this system became operational) three flood events with discharges greater than $100 \mathrm{~m}^{3} \mathrm{~s}^{-1}$ and twelve flood events with discharges less than $100 \mathrm{~m}^{3} \mathrm{~s}^{-1}$ were recorded. Based on these records, ten events were selected for the calibration and validation stages. The original temporal resolution of five minutes was chosen to accurately simulate the occurrence of infiltration excess overland flow. This runoff production mechanism is usually linked to high rainfall intensities during rather short periods (Bronstert and Bárdossy, 2003), which are typical in this hydro-climatic region. The calibration was performed using the greatest event occurring in October 2000 and using the root mean square error (RMSE) as the objective function. It is shown in Fig. 7a. The hydrograph was well-represented with an error in the peak discharge of about $0.2 \%$, the Nash-Sutcliffe efficiency (NSE) index was 0.82 and the RMSE-observation standard deviation ratio (RSR according to Moriasi et al., 2007) was found to be about 0.42 . The model validation showed a good representation of other nine recorded hydrographs. The peak discharge error was less than $8.5 \%$ in all cases, NSE ranged between 0.51 and 0.75 and RSR between 0.50 and 0.70 . Using the reference values of general performance ratings for recommended statistics given by Moriasi et al. (2007), the results in terms of both NSE and RSR were very good in the calibration stage and between satisfactory and very good in the validation stage. In the calibration and validation stages, the initial soil water contents were estimated by automatic 
optimisation, giving reasonable values according to continuous simulation at daily scale with the support of the regional rain gauge network operated by the Meteorology Spanish Agency. The results of the modelled events showed that the main component of the total discharge was the overland flow, as was found by Camarasa and Segura (2001).

For the Upper Iller catchment, a total of 11 rain gauges and 8 runoff gauges were used. In the WASIM-ETH model, a model time discretisation of one day was applied for the establishment of initial conditions, while the actual simulations were carried out using hourly time steps. A regression-based method was used to improve input data to solve the problem of the strong gradient of temperature and precipitation with altitude, which is often not captured by the available climate station data. The calibration was carried out for each subcatchment separately for the time period March-September 2002. During the calibration phase, downstream subcatchments received measured discharge time series from their respective upstream counterparts. This ascertains that model errors from upstream catchments are not compensated by the parameters determined for the lower catchments. The model performance showed balance errors between $4 \%$ and $23 \%$ and NSE indices between 0.78 and 0.87 , which is quite high given the above described difficulties with the input data. Figure $7 \mathrm{~b}$ shows the results for the lowest subcatchment. In most cases base flow is only produced at a very low level, with interflow taking over and providing streamflow during periods between rainfall events. Only one subcatchment had a higher interflow component producing event dynamics instead of overland flow. It is only during the snow melt period as well as during larger rainfall events that a pronounced and strong response in overland flow occurs. Model validation was carried out for the March-August 2005 period, with one year as warming-up period. As the discharge time series of most gauging stations have one or more gaps of at least several months, validation was only carried out for one of the headwater subcatchments. In this case, the validation was very good with a NSE of 0.86 .

For the development of the distributed model at the Kamp catchment, data from 16 rain gauges were used. Of these, 10 rain gauges had 15 -min recording intervals while the others were daily gauges. Climatologically scaled radar information was used to interpolate input data at each time step in the model. Additionally, spatially distributed air temperature grids were interpolated, based on observed air temperatures recorded at eight gauging stations in the study catchment. The gridded meteorological input data were used to simulate state variables such as soil moisture, reservoir storage and snow water equivalent at each modelling time step. For the development of the distributed model, discharge data between 1993 and 2005 from Zwettl station were used. The simulations were compared with observed runoff data at a seasonal scale and at the event scale stratified by hydrological situations. Event analysis was stratified by magnitude and event types as synoptic (large scale), convective (small
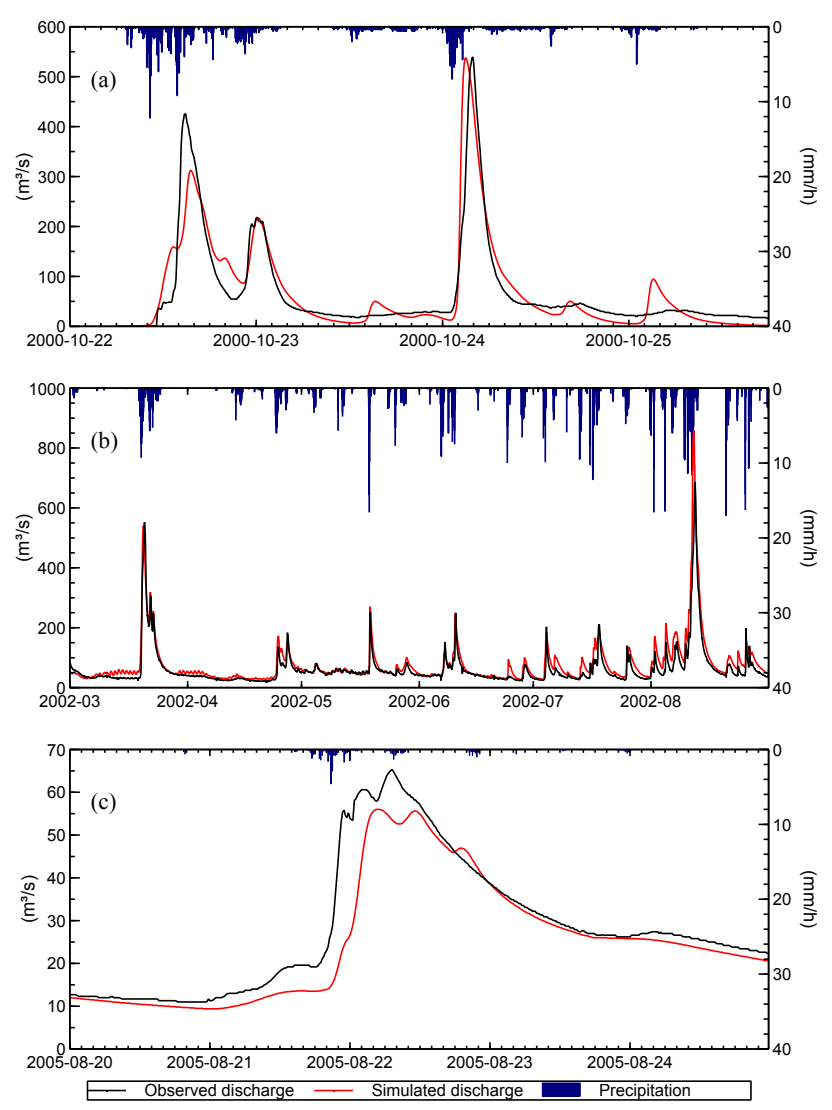

Fig. 7. Calibration periods at catchments: (a) Poyo, (b) Upper Iller and (c) Kamp.

scale), snow melt, and rain-on-snow events. During the calibration and validation process hydrologic reasoning based on field surveys, expert knowledge from local water professionals and additional data sets (e.g., ground-water levels) was used as external information to test the plausibility of the model structure and parameters. The model performance for the entire simulation period (from October 1993 to August 2005 ) with a NSE of 0.88 and a balance error about $5 \%$ was very good. The result for a convective event (August 2005) is shown in Fig. 7c: the hydrograph was very well represented with an error in the peak discharge of about $14 \%$, with a NSE index of 0.84 .

\subsection{Effects of afforestation}

Figure 8 shows that in the case of small storms, the peak flow reduction reached values of one-third for Poyo and Kamp catchments and about one-fifth for the Upper Iller catchment, but it was nearly zero for the largest events in all study areas. Figure 8 shows that the potential effect of afforestation on peak flow reduction decreases when the event magnitude increases. This plot shows that there is a considerable similarity in tendencies among all our case studies. This behaviour is due to the role of interception and soil moisture deficit of 


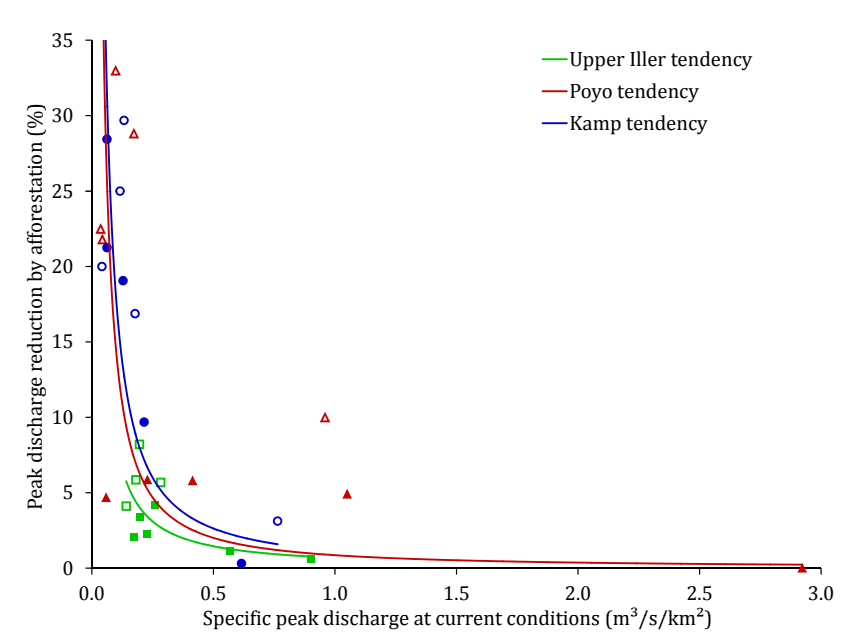

Fig. 8. Effect of the afforestation scenario on peak discharge with two initial soil moisture conditions (solid symbols means "wet" and empty symbols means "dry") in the catchments: (a) Poyo (red triangles), (b) Upper Iller (green squares) and (c) at Kamp (blue circles). MAISC values are 4.0, 3.2 and $7.8 \mathrm{~mm}$, respectively.

the forest in the rainfall abstraction, which can represent a significant proportion of rainfall volume in the case of small storms, but is relatively insignificant for the largest rainfall events (Calder and Aylward, 2006). Although these results agree with the predominant findings in forest hydrology, recent studies showed a contrary effect, that the effects of this land use change remain important even for extreme floods. Hicks et al. (2005) combined field methods with modelling to analyse the flood response of a small Appalachian catchment $\left(2.1 \mathrm{~km}^{2}\right)$ to a largest event. They concluded that even under extreme rainfall conditions, land use (45\% forested and $55 \%$ grass/pasture) can play a role in determining the magnitude and timing of flood peaks at small scales. Kuras et al. (2012) used a modelling-based investigation on a planned forest harvesting $\left(50 \%\right.$ of a catchment with $4.74 \mathrm{~km}^{2}$ located in south central British Columbia), where the effect on peak reduction $(9 \%-25 \%)$ increased with return period (10-100 yr). It was attributable to the snow-dominated runoff generation processes in the catchment. A possible explanation for these differences in findings may be due to different factors related to catchment size such as peak discharge synchronisation, the proportionate change in land use and rainfall spatial scale (Calder and Aylward, 2006). Calder and Aylward (2006) stated that "although land use change effects on floods may be detectable on small catchments the "signal" is likely to be weaker on large catchments".

Regarding the effect of initial soil moisture, Fig. 8 shows that in general terms, this kind of measure tends to be more effective in peak discharge reduction with dry initial conditions than with wet initial conditions. This is because with wetter initial conditions the interception storage is rapidly saturated and the infiltration capacity is smaller (López-
Moreno et al., 2006). Figure 8 and Table 7 show effectiveness as a function of MAISC index, where the lower the MAISC value, the lower the peak discharge reduction. The small difference in the upper quartiles between Kamp and Poyo (Table 7) could be due to the particular flood-producing rainfall characteristics of their hydro-climate regimes: Poyo has a drier regime than Kamp. The effect of land use measures strongly depends on antecedent conditions and on the type of precipitation, as concluded by Niehoff et al. (2002) and by Hooijer et al. (2004). Additionally, the potential of flood control by land-use management measures is also dependent on the site-specific soil and relief conditions (Wahren et al., 2007).

The tendency line of the Poyo case study (red line in Fig. 8) shows the influence of the afforestation scenario on the ten historical events that were simulated. The largest event was not mitigated (peak reduction was almost insignificant) because it was a long event of large magnitude, with high-intensity intervals and wet initial soil moisture conditions. This effect was found also by Bellot et al. (2001) in one small Mediterranean catchment $\left(\sim 6 \mathrm{~km}^{2}\right)$. For the remaining long events (which were generally of medium magnitude) flow peak reductions ranged between 5-6\% for wet and $10 \%$ for dry initial soil moisture condition. For summer convective storms (which were generally of low magnitude and exhibiting dry antecedent conditions), reductions of about 22-33\% were found. These values of peak reduction agree with the results found in similar hydro-climatological regions by both Cognard-Plancq et al. (2001) with annual flood peak reductions up to $20 \%$ and with the results found by Cossandey et al. (2005) who reported reductions of about $31 \%$ for the annual peak floods and $5 \%$ for 10 -yr peak floods.

The tendency line of the Upper Iller catchment (green line in Fig. 8) shows the peak flow reduction was between $2 \%$ and $8 \%$ : very small for extreme floods with peak discharges above $300 \mathrm{~m}^{3} \mathrm{~s}^{-1}\left(>0.3 \mathrm{~m}^{3} \mathrm{~s}^{-1} \mathrm{~km}^{-2}\right)$ and rather moderate for small and medium floods. The results for small and medium floods were found to have the same order of magnitude as that found in the study by Papankova et al. (2006) for events between 2 and $50 \mathrm{yr}$ return period for an afforestation scenario in the Hron River basin (central Slovakia). The kind of soils in the Upper Iller catchment could be another reason why there is little effect on peak flow reduction. On shallow soils and low-permeable bedrock, subsurface flow processes are quite important as was observed in this study as well as in another given by Bronstert et al. (2007) for one subcatchment of the Rhine River basin located in the Maritime-Continental hydro-climatic region.

The tendency line of the Kamp study (blue line in Fig. 8) shows the influence of afforestation scenario on the ten flood events at the Zwettl/Kamp gauge station. The effect of this land use change is very small for extreme floods with peak discharges above $350 \mathrm{~m}^{3} \mathrm{~s}^{-1}\left(>0.5 \mathrm{~m}^{3} \mathrm{~s}^{-1} \mathrm{~km}^{-2}\right)$. For smaller events, the influence of land-use change starts to be significant with peak reductions of up to $30 \%$. These 
Table 7. Peak discharge reduction quartiles for the afforestation scenarios (more optimistic giving different MAISC at each catchment).

\begin{tabular}{llll}
\hline MAISC $(\mathrm{mm})$ & 3.2 & 4.0 & 7.8 \\
\hline Quartile & Upper Iller & Poyo & Kamp \\
\hline Minimum & $0.6 \%$ & $0.0 \%$ & $0.0 \%$ \\
First & $2.1 \%$ & $5.1 \%$ & $11.5 \%$ \\
Second & $3.7 \%$ & $7.9 \%$ & $19.5 \%$ \\
Third & $5.3 \%$ & $22.3 \%$ & $24.1 \%$ \\
Maximum & $8.2 \%$ & $33.0 \%$ & $29.7 \%$ \\
\hline
\end{tabular}

results agree with the findings in the Poyo catchment: the two case studies indicate that the systematic afforestation of agricultural areas will reduce peak flows for small and medium events, but with no reduction for large events. Also, these results agree with some findings in the same hydroclimatic region. In the Schwarze Pockau catchment in Germany $\left(129 \mathrm{~km}^{2}\right)$, Wahren et al. (2007) found a decrease in peak flow of $24 \%$ in the flood-producing heavy rainfall event, $21 \%$ for a typical frequent event and practically no effect $(3 \%)$ for the highly infrequent event from August 2002 (which contributed to the devastating "Elbe flood" event). Merta et al. (2008) analysed the effects of several scenarios in the Weißeritz catchment (German-Czech border) in terms of both reduction of areas with quick runoff components and reduction of peak discharge. One of these scenarios was a partial afforestation on Höckenbach subcatchment $\left(16.7 \mathrm{~km}^{2}\right)$ where peak flow reductions were less than $20 \%$ for intense but short summer rain events, depending on the recurrence intervals and was higher for the most frequent events. In the case of rain events with longer duration the peak discharge could be reduced by up to $10 \%$.

\subsection{Effects of landscape retention elements: small-reservoirs and micro-ponds}

Retention elements at headwater channel networks with a low MAISC index (small-reservoirs with a MAISC equal to $0.47 \mathrm{~mm}$ at both Poyo and Upper Iller) were shown to have limited effects on peak flows (peak reduction quartile values are shown in Table 8). The low effectiveness of this kind of measure can be explained by the low increment in retention capacity and the runoff generation in areas downstream of the small-reservoirs. In fact, the topography and size of the Iller catchment (Iller is 5.2 times bigger than Poyo) forced a worst distribution of the small-reservoirs and consequently a smaller peak discharge reduction than in Poyo catchment. This confirms the statements by Leopold and Maddock (1954) who argued that a series of small headwater dams were ineffective during the biggest floods at large catchments scales. Also, Hooijer et al. (2004) found that retention measures along upstream channels may help reduce

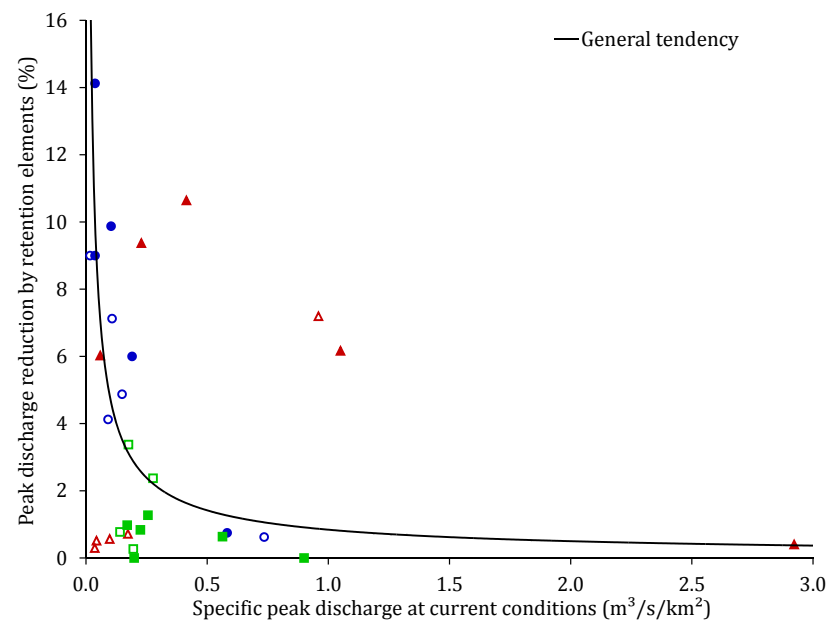

Fig. 9. Effect of the flood retention measures on peak discharge in the catchments outlets considering the same MAISC equal to $1.2 \mathrm{~mm}$ and two initial soil moisture conditions: solid symbols means "wet" and empty symbols means "dry". Catchments: (a) small-reservoirs at Poyo (red triangles), (b) micro-ponds at Upper Iller (green squares) and (c) micro-ponds at Kamp (blue circles).

flood risk in the upstream sub-basins, but will contribute little to flood risk reduction far downstream.

In the case of retention elements at hillslopes using microponds, with a MAISC equal to $1.2 \mathrm{~mm}$ for both Upper Iller and Kamp, there was greater effectiveness than in the smallreservoir scenarios, but the difference was moderate, as can be seen in Table 8 . The differences between Iller and Kamp in the magnitude of peak flow reduction can be attributed to the same situation seen in the small-reservoirs; i.e., Upper Iller catchment is 1.5 times larger than Kamp and it has a higher probability of runoff generation on drainage areas located downstream from the measurement locations. Notice also that for retention elements on hillslopes, MAISC is three times higher than for retention elements within the channel network. Table 8 shows that for the scenarios with MAISC values of about 1.2, effectiveness was greater than for scenarios with values of about $0.47 \mathrm{~mm}$. For a large river basin and large reservoirs, Batalla et al. (2004) used the ratio of reservoir capacity to mean annual runoff and concluded that, when this ratio increased, flood frequency and magnitude decreased.

Results from Table 8 show that, for the same MAISC, small-reservoirs were more effective at Poyo than microponds at Iller, but micro-ponds were slightly more effective at Kamp than small-reservoirs at Poyo. Therefore, other local factors are playing a significant role in the effectiveness of flood attenuation. For all case studies, the tendency line in Fig. 9 indicates that, in general, peak discharge reduction is higher for lower peak discharge magnitudes and vice versa. A similar tendency was observed by López-Moreno et al. (2002) through time-series analysis, 
Table 8. Peak discharge reduction quartiles for the retention elements in the landscape scenarios.

\begin{tabular}{lll|lll}
\hline MAISC (mm) & \multicolumn{2}{c|}{0.47} & \multicolumn{2}{c}{1.2} & \\
\hline Quartile & $\begin{array}{l}\text { Upper Iller, } \\
\text { small- } \\
\text { reservoirs }\end{array}$ & $\begin{array}{l}\text { Poyo, } \\
\text { small- } \\
\text { reservoirs }\end{array}$ & $\begin{array}{l}\text { Upper Iller, } \\
\text { micro-ponds }\end{array}$ & $\begin{array}{l}\text { Poyo, } \\
\text { small- } \\
\text { reservoirs }\end{array}$ & $\begin{array}{l}\text { Kamp, } \\
\text { micro-ponds }\end{array}$ \\
\hline Minimum & $0.0 \%$ & $0.0 \%$ & $0.0 \%$ & $0.0 \%$ & $0.6 \%$ \\
First & $0.0 \%$ & $0.5 \%$ & $0.4 \%$ & $0.5 \%$ & $4.3 \%$ \\
Second & $0.0 \%$ & $2.4 \%$ & $0.8 \%$ & $3.6 \%$ & $6.6 \%$ \\
Third & $0.4 \%$ & $6.1 \%$ & $1.2 \%$ & $10.8 \%$ & $9.0 \%$ \\
Maximum & $0.8 \%$ & $7.2 \%$ & $3.4 \%$ & $12.8 \%$ & $14.1 \%$ \\
\hline
\end{tabular}

but analysing only one large reservoir. Similarly, Chen et al. (2007) found that the effectiveness of analogous measures decreased whilst flood event characteristics increased. Figure 9 separates events according to dry and wet antecedent soil moisture conditions. While flood retention measures (small-reservoirs and micro-ponds) were more effective during events with wet initial conditions than for dry events for the Poyo and Kamp catchments, at the Upper Iller catchment there was no clear relationship. Each case study was analysed separately in an effort to explain this different behaviour.

In the case of the Poyo catchment (red triangles in Fig. 9) a clear pattern was found as a function of the event characteristics. Peak discharge reduction in summer convective rainstorms with small magnitudes, short duration and dry initial conditions were almost insignificant. Flood genesis in these cases was due to flashiness responses in the lowest part of the catchment. In these areas the effect of the set of smallreservoirs is almost nil because they are distributed at headwater and middle areas of the catchment. For longer storm events affecting larger areas of the catchment, the runoff generated and concentrated at headwaters can be captured by the small-reservoirs, affecting more significantly the peak discharge at the outlet. As expected, this influence diminishes when event magnitude increases.

The micro-pond scenario in Upper Iller catchment was clearly more effective than small-reservoirs for smaller events, but the difference diminishes with larger floods. The events analysed for the peak reduction study were separated into events with wet antecedent conditions and events with dry antecedent conditions. For the headwater subcatchment we found that, in general, both micro-ponds and smallreservoirs were more effective for dry antecedent conditions whereas no clear pattern was observed for the entire catchment. These results might be caused by the small sample size and a mixing of effects such as location of runoff generation and event characteristics (magnitude, duration and antecedent conditions).

Circles in Fig. 9 represent the influence of micro-ponds on ten historical flood events simulated in the Kamp catchment. The peak discharge reduction rapidly decreases with larger flood peaks. The influence of the micro-ponds on flood
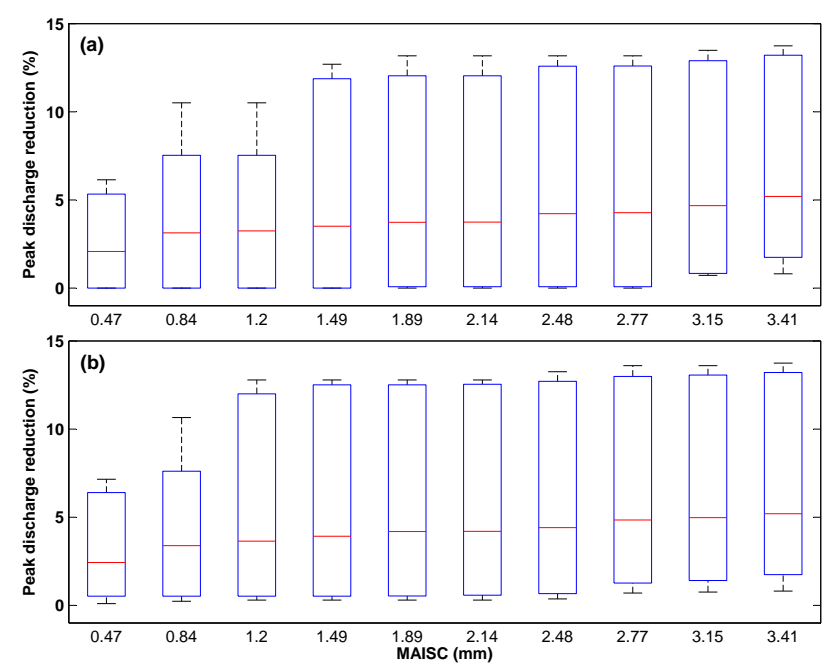

Fig. 10. Effect of MAISC and two different small-reservoirs spatial distribution in the Poyo catchment: (a) more concentred at headwater areas and (b) distributed both at headwater and at middle areas.

response was examined for different event types. For small events, mostly convective events, flood peak reductions of up to $14 \%$ were observed. For extreme flood events with peak discharges above $350 \mathrm{~m}^{3} \mathrm{~s}^{-1}\left(>0.5 \mathrm{~m}^{3} \mathrm{~s}^{-1} \mathrm{~km}^{-2}\right)$, the potential reduction of the micro-ponds is nearly zero. In the case of extreme events that occur when large parts of the catchment are already saturated after the first intensive rainfall, the reduction in soil moisture due to the construction of microponds has only a small effect on the flood peak. The peak reduction through micro-ponds is higher for wet initial conditions. This is due to the fact that the fraction of surface runoff is greater in the case of high soil moisture and more water drains into the micro-ponds.

As a final analysis, Fig. 10 shows the peak discharge reduction as a function of a wide range of MAISC values in the Poyo basin with two small-reservoirs configurations: (a): more concentrated in headwaters areas; and (b) with some small-reservoirs located in the middle basin. In both cases, a greater MAISC is associated with a greater mean and upper 
quartile of peak discharge reduction. In addition, for similar MAISC values, the set of reservoirs influencing headwater and middle areas showed higher peak reductions than the other set which mainly influences headwater areas. This effect was more accentuated for MAISC values lower than $1.49 \mathrm{~mm}$.

\subsection{Applicability and limitations}

The model evaluation demonstrated that physical dominant processes in the studied catchments have been simulated appropriately for the reference period. The model performances were satisfying with respect to runoff simulations, but could be checked only qualitatively due to limited observations. On this basis, it is assumed that the models are capable of performing projections based on the characteristics prevailing in the catchment. Parameters changes should be considered when analysing the effects of flood management measures in scenarios studies providing that the model assumptions made in this approach are valid. As was discussed above, the effect of the measures depend on different factors such as rainfallproducing floods, soil moisture antecedent conditions, soil characteristics, catchment size, relative storage capacity in the catchment and measurement location. But, the results also depend on each model conceptualisation and parameterisation. Although these effects are likely to be specific in each catchment, the results showed similar tendencies in all catchment investigated. These results should be representative for other catchments in similar hydro-climatic regions.

The results also showed that each hydrological model has different sensitivities related to the assumed parameter changes. Although the quantification of the uncertainties underlying this approach are beyond the scope of this study, it should be considered in subsequent analysis. To this end, there is a wide body of literature. For example, Nandakumar and Mein (1997) quantified the levels of uncertainty in rainfall-runoff model predictions due to the errors in hydrological and climatic data and considered the implications for prediction of the hydrologic effect of land-use changes. Also, an approach to assess the effects of different land covers on model outputs was given by Eckhardt et al. (2003). Methods to ensemble different models were presented by Huisman et al. (2009) where the probabilistic reliability ensemble averaging method allowed a quantification of the model structure uncertainty in the land use scenario predictions. The latter has become standard practice in analysis of predictions of future climate.

\section{Conclusions and recommendations}

This study covered a wide spectrum of hydrological processes in catchments located in different hydroclimatological regions in Europe (Mediterranean, Alpine and Continental). The respective processes have been ad- equately represented with a physical meaning using distributed process-oriented hydrological models and a proper model identification and parameterisation. According to standard model evaluation techniques (Moriasi et al., 2007), the three models (TETIS, WATSIM-ETH and KAMPUS) produced performance rating from satisfactory to very good simulations for the reference period. The use of the fitted models for modelling assumed flood management scenarios was possible and potentially useful for planning purposes. However, the uncertainties of this kind of approach due to typical errors related to model structure, parameters and input data are of major importance. A way to demonstrate the model transferability should be implemented using data from a wide range of climatic conditions and with an ensemble of different models or, possibly, with an ensemble of a given model using different parameter sets (Duan et al., 2006). Huisman et al. (2009) applied an ensemble of hydrological models to analyse the same set of land use change scenarios, increasing their confidence in the scenario predictions. However, they suggest its use in a well-instrumented catchment that has experienced, or is still experiencing, land use change.

The combination of comparative analysis and modelbased scenario assessment has helped to find general tendencies in spite of the particular differences among studied areas. The results possibly depend on both specific catchment characteristics and specific model assumptions, but the individual effects were similar for all catchment studied. As was concluded by Robinson et al. (2003) a relative consistency of results between regions gives confidence in the generality of the findings. Therefore, these results could be representative for other catchments in similar hydro-climatic regions. In general terms, the potential capacity for flood peak reduction through the concept of "retaining water in the landscape" (i.e., the effectiveness of the particular measures analysed) is clearly a function of the relative storage capacity in the catchment and the event magnitude. This relative storage capacity can be measured by the MAISC index. Also, the effectiveness is dependent upon the rainfall characteristics and antecedent soil moisture conditions, and it is controlled by the spatial distribution of the retention measures within the catchment.

In general, the strategy of "retaining water in the landscape" through decentralised measures such as afforestation, small-reservoirs and micro-ponds could play an important role for flood management in meso-scale catchments for small and medium events, but has almost negligible effects during the largest flood events. Although a hazard reduction will be expected using these measures, especially for frequent floods, it is necessary to put these results in the context of flood risk management because the vulnerability has not changed. Therefore, the social awareness of potential flood damage during large floods needs to be increased to counteract the fact that the population is experiencing floods less 
frequently and is thus no longer regularly reminded of this particular risk.

In particular, afforestation and micro-ponds may also have other benefits. Afforestation could play an important role in preventing landslides and related flood processes as it protects the soil from temperature and moisture extremes, as well as offering protection against erosional forces such as raindrop impact (Jewitt, 2005), especially on steep slopes. These effects are likely to be site and possibly event specific (Calder and Aylward, 2006). Micro-ponds managed in conjunction with ecologically sound agricultural practices may help to improve water quality (De Laney, 1995).

Finally, we want to make two sets of recommendations. First, we suggest that the following should be considered for future research in this area:

1. An analysis beyond individual hydrographs or discharge time series when examining changes in the flood frequency curve as a support for the analysis of changes in both flood hazard and flood risk (O'Connell et al., 2007).

2. Recent studies call for interdisciplinary frameworks to take into account the ongoing hydro-climatic changes in the context of water-resource risk assessment and planning. To this end, Milly et al. (2008) suggest that future water management measures and landscape changes should be routinely included in climate models. Alternative techniques to the current scenario approach such as the so-called sensitive methods and trading space for time can add more credibility to model projections (Peel and Blöschl, 2011). Merz et al. (2011) suggest the use of models which can use hydrological response data other than outlet discharges to identify model structures capable of representing hydrological processes in a changing world.

Different strategies for parameter changes due to the proposed measures were presented as a function of the model and available information. But, in the case of afforestation scenarios, we found a high uncertainty when translating hydrological characteristics from the real world to the hydrological model parameters. So, in our second set of recommendations, we suggest the following:

1. Estimated changes in model parameters could be supported by the use of physical or empirical relationships with uncertainty analysis (Wagener, 2007).

2. A review of experimental results about infiltration features of top soils and the hydraulic soil conductivities as a function of forest state, development and age. In this respect, a series of field experiments should be considered to add data about the response of these important parameters where needed.
3. Due to the complexity of the interacting processes that could be affected by land use changes and their feedbacks at large spatial scales (Calder and Aylward, 2006), it is necessary to conduct more studies at the catchment scale, as in the project led by the Flood Risk Management Research Consortium in UK (FRMRC, 2012) and using different data sources (Bulygina et al., 2012).

Acknowledgements. Most of this research was done within the ERANET-Crue project "Room for the River", which was sponsored by: Lebensministerium (Austria), Bundesministerium für Bildung und Forschung (Germany) and Ministerio de Ciencia y Educación (Spain). We would like to thank each basin authority and national weather agencies for providing the hydro-meteorological data. The authors would like to thank to the Editor Andreas Günther and two anonymous referees for their valuable comments.

Edited by: A. Günther

Reviewed by: two anonymous referees

\section{References}

Batalla, R. J., Gomez, C. M., and Kondolf, G. M.: Reservoirinduced hydrological changes in the Ebro River basin (NE Spain), J. Hydrol., 290, 117-136, 2004.

Bellot, J., Bonet, A., Sanchez, J., and Chirino, E.: Likely effects of land use changes on the runoff and aquifer recharge in a semiarid landscape using a hydrological model, Landscape Urban Plann., 55, 41-53, 2001.

Beven, K. J.: Predicting the effects of change, in: Rainfall-Runoff Modelling - The Primer, Wiley, Chichester, 277-295, 2001.

Blöschl, G., Ardoin-Bardin, S., Bonell, M., Dorninger, M., Goodrich, D., Gutknecht, D., Matamoros, D., Merz, B., Shand, P., and Szolgay, J.: At what scales do climate variability and land cover change impact on flooding and low flows?, Hydrol. Process., 21, 1241-1247, doi:10.1002/hyp.6669, 2007.

Blöschl, G., Reszler, C., and Komma, J.: A spatially distributed flash flood forecasting model, Environ. Model. Soft., 23, 464478, 2008.

Bronstert, A.: Rainfall-runoff modelling for assessing impacts of climate and land-use change, Hydrol. Process., 18, 567-570, 2004.

Bronstert, A. and Bárdossy, A.: Uncertainty of runoff modelling at the hillslope scale due to temporal variations of rainfall intensity, Phys. Chem. Earth, 28, 283-288, 2003.

Bronstert, A., Bárdossy, A., Bismuth, C., Buiteveld, H., Disse, M., Engel, H., Fritsch, U., Hundecha, Y., Lammersen, R., and Niehoff, D.: Multi-scale modelling of land-use change and river training effects on floods in the Rhine basin, River Res. Applic., 23, 1102-1125, 2007.

Bulygina, N., Ballard, C., McIntyre, N., O'Donnell, G., and Wheater, H.: Integrating different types of information into hydrological model parameter estimation: application to ungauged catchments and land use scenario analysis, Water Resour. Res., 48, W06519, doi:10.1029/2011WR011207, 2012. 
Calder, I. R. and Aylward, B.: Forest and floods: Moving to an evidence-based approach to watershed and integrated flood management, Water Int., 31, 87-99, 2006.

Camarasa, A. M. and Segura, F.: Flood events in Mediterranean ephemeral streams (ramblas) in Valencia region, Spain, Catena, 45, 229-249, 2001.

Chen, C. N., Tsai, C. H., and Tsai, C. T.: Reduction of discharge hydrograph and flood stage resulted from upstream detention ponds, Hydrol. Process., 21, 3492-3506, 2007.

Cognard-Plancq, A. L., Marc, V., Didon-Lescot, J. F., and Normand, M.: The role of forest cover on streamflow down subMediterranean mountain watersheds: a modelling approach, J. Hydrol., 254, 229-243, 2001.

Cossandey, C., Andreassian, V., Martin, C., Didon-Lescot, J. F., Lavabre, J., Folton, N., Mathys, N., and Richard, D.: The hydrological impact of the Mediterranean forest: a review of french research, J. Hydrol., 301, 235-249, 2005.

De Laney, T. A.: Benefits to downstream flood attenuation and water quality as a result of constructed wetlands in agricultural landscapes, J. Soil Water Conserv., 50, 620-626, 1995.

Disse, M. and Engel, H.: Flood events in the Rhine Basin: Genesis, influences and mitigation, Nat. Hazards, 23, 271-290, 2001.

Doherty, J.: PEST - Model-Independent Parameter Estimation, User Manual: 5th Edition, 2005.

Duan, Q., Sorooshian, S., and Gupta, V. K.: Optimal use of the SCEUA global optimisation method for calibrating watershed models, J. Hydrol., 158, 265-284, 1994.

Duan, Q., Schaake, J., Andréassian, V., Franks, S., Goteti, G., Gupta, H., Gusev, Y., Habets, F., Hall, A., Hay, L., Hogue, T., Huang, M., Leavesley, G., Liang, X., Nasonova, O. N., Noilhan, J., Oudin, L., Sorooshian, S., Wagener, T., and Wood, E. F.: Model Parameter Estimation Experiment (MOPEX): An overview of science strategy and major results from the second and third workshops, J. Hydrol., 320, 3-17, 2006.

Eckhardt, K., Breuer, L., and Frede, H.-G.: Parameter uncertainty and the significance of simulated land use change effects, J. Hydrol., 273, 164-176, 2003.

Francés, F., Vélez, J. I., and Vélez, J. J.: Split-parameter structure for the automatic calibration of distributed hydrological models, J. Hydrol., 332, 226-240, doi:10.1016/j.jhydrol.2006.06.032, 2007.

FRMRC: Flood Risk Management Research Consortium, http:// www.floodrisk.org.uk/, last access: 17 April 2012.

Grayson, R. and Blöschl, G.: Summary of pattern comparison and concluding remarks, in: Spatial Patterns in Catchment Hydrology: Observations and Modelling, edited by: Grayson, R. and Blöschl, G., Cambridge University Press, UK, 355-367, 2000.

Hall, J. W., Meadowcroft, I. C., Sayers, P. B., and Bramley, M. E.: Integrated Flood Risk Management in England and Wales, Nat. Hazards Rev., 4, 126-135, 2003.

Hicks, N. S., Smith, J. A., Miller, A. J., and Nelson, P. A.: Catastrophic flooding from an orographic thunderstorm in the central Appalachians, Water Resour. Res., 41, W12428, doi:10.1029/2005WR004129, 2005.

Hooijer, A., Klijn, F., Pedroli, G. B. M., and Van Os, A. G.: Towards sustainable flood risk management in the Rhine and Meuse river basins: synopsis of the findings of IRMA-SPONGE, River Res. Applic., 20, 343-357, 2004.
Huisman, J. A., Breuer, L., Bormann, H., Bronstert, A., Croke, B. F. W., Frede, H. G., Gräff, T., Hubrechts, L., Jakeman, A., Kite, G., Lanini, J. , Leavesley, G., Lettenmaier, D. P. , Lindström, G., Seibert, J., Sivapalan, M., Viney, N. R., and Willems, P.: Assessing the impact of land use change on hydrology by ensemble modeling (LUCHEM). III: Scenario analysis, Adv. Water Resour., 32, 159-170, 2009.

Hundecha, Y. and Bárdossy, A.: Modeling of the effect of land use changes on the runoff generation of a river basin through parameter regionalization of a watershed model, J. Hydrol., 292, 281-295, 2004.

Jewitt, G.: Water and forests, in: Encyclopedia of Hydrological Sciences, edited by: Anderson, M. G. and McDonnell, J. J., John Wiley \& Sons Ltd, Chichester, UK, 2897-2909, 2005.

Klemeš, V.: Operational testing of hydrological simulation models/Vérification, en conditions réelles, des modèles de simulation hydrologique, Hydrolog. Sci. J., 31, 13-24, 1986.

Klöcking, B. and Haberlandt, U.: Impact of land use changes on water dynamics-a case study in temperate meso and macroscale river basins, Phys. Chem. Earth, 27, 619-629, 2002.

Kundzewicz, Z. W. and Takeuchi, K.: Flood protection and management: quo vadimus?, Hydrolog. Sci. J., 44, 417-432, 1999.

Kuras, P. K., Alila, Y., and Weiler, M.: Forest harvesting effects on the magnitude and frequency of peak flows can increase with return period, Water Resour. Res., 48, W01544, doi:10.1029/2011WR010705, 2012.

Leopold, L. B. and Maddock, Jr T.: The Flood Control Controversy, The Ronald Press, New York, 278 pp., 1954.

López-Moreno, J. I., Beguería, S., and García-Ruiz, J. M.: Influence of the Yesa reservoir on floods of the Aragón River, central Spanish Pyrenees, Hydrol. Earth Syst. Sci., 6, 753-762, doi:10.5194/hess-6-753-2002, 2002.

López-Moreno, J. I., Beguería, S., and García-Ruiz, J. M.: Trends in high flows in the central Spanish Pyrenees: response to climatic factors or to land-use change?, Hydrolog. Sci. J., 51, 1039-1050, 2006.

Merta, M., Seidler, C., Bianchin, S., Heilmeier, H., and Richert, E.: Analysis of Land Use Change in the Eastern Ore Mts. Regarding Both Nature Protection and Flood Prevention, Soil Water Res., 3, S105-S115, 2008.

Merz, R., Parajka, J., and Blöschl, G.: Time stability of catchment model parameters: Implications for climate impact analyses, Water Resour. Res., 47, W02531, doi:10.1029/2010WR009505, 2011.

Milly, P., Betancourt, J., Falkenmark, M., Hirsch, R. M., Kundzewicz, Z. W., Lettenmaier, D. P., and Stouffer, R. J.: Stationarity is dead: whither water management?, Science, 319, doi:10.1126/science.1151915, 573-574, 2008.

Moriasi, D., Arnold, J., Van Liew, M., Bingner, R., Harmel, R., and Veith, T.: Model evaluation guidelines for systematic quantification of accuracy in watershed simulations, Transactions of the ASABE, 50, 885-900, 2007.

Nandakumar, N. and Mein, R. G.: Uncertainty in rainfall-runoff model simulations and the implications for predicting the hydrologic effects of land-use change, J. Hydrol., 192, 211-232, 1997.

Niehoff, D., Fritsch, U., and Bronstert, A.: Land-use impacts on storm-runoff generation: scenarios of land-use change and simulation of hydrological response in a meso-scale catchment in SW-Germany, J. Hydrol., 267, 80-93, 2002. 
O’Connell, P. E., Ewen, J., O’Donnell, G., and Quinn, P.: Is there a link between agricultural land-use management and flooding?, Hydrol. Earth Syst. Sci., 11, 96-107, doi:10.5194/hess-11-962007, 2007.

Panagos, P., Van Liedekerke, M., Jones, A., and Montanarella, L.: European Soil Data Centre: Response to European policy support and public data requirements, Land Use Policy, 29, 329-338, 2012.

Papankova, Z., Horvat, O., Hlavcova, K., Szolgay, J., and Kohnova, S.: Scenarios of flood regime changes due to land use change in the Hron river basin, in: Transboundary Floods: Reducing Risks Through Flood Management, edited by: Marsalek, J., Stancalie, G, and Balint, G., Springer, The Netherlands, 99-110, 2006.

Parajka, J., Merz, R., and Blöschl, G.: Regionale Wasserbilanzkomponenten für Österreich auf Tagesbasis (Regional water balance components in Austria on a daily basis), Österreichische Wasserund Abfallwirtschaft, 57, 43-56, 2005.

Peel, M. C. and Blöschl, G.: Hydrological modelling in a changing world, Prog. Phys. Geogr., 35, 249-261, doi:10.1177/0309133311402550, 2011.

Plate, E. J.: HESS Opinions "Classification of hydrological models for flood management”, Hydrol. Earth Syst. Sci., 13, 1939-1951, doi:10.5194/hess-13-1939-2009, 2009.

Ponce, V. M.: Engineering hydrology: Principles and practices, Prentice Hall Inc., New Jersey, USA, 1989.

Robinson, M., Cognard-Plancq, A. L., Cosandey, C., David, J., Durand, P., Führer, H. W., Hall, R., Hendriques, M., Marc, V., and McCarthy, R.: Studies of the impact of forests on peak flows and baseflows: a European perspective, For. Ecol. Manage., 186, 8597, 2003.
Samuels, P., Gouldby, B., Klijn, F., Messner, F., van Os, A., Sayers, P., Schanze, J., and Udale-Clarke, H.: Language of Risk-Project Definitions (Second Edition), FLOODsite report number T3204-01, 55 pp., 2009.

Schulla, J. and Jasper, K.: Model description WASIM-ETH, Technical report, 81 pp., 2007.

Schumann, A. H.: Introduction-Hydrological Aspects of Risk Management, in: Flood Risk Assessment and Management, edited by: Schumann, A. H., Springer, 1-10, 2011.

Valdes, J. B. and Marco, J. B.: Managing reservoirs for flood control, in: Proceedings of the US-Italy Research Workshop on the Hydrometeorology, Impacts, and Management of Extreme Floods, Perugia, Italy, November 1995, 1-13, 1995.

Vélez, J. J., Puricelli, M., López Unzu, F., and Francés, F.: Parameter extrapolation to ungauged basins with a hydrological distributed model in a regional framework, Hydrol. Earth Syst. Sci., 13, 229-246, doi:10.5194/hess-13-229-2009, 2009.

Wagener, T.: Can we model the hydrological impacts of environmental change?, Hydrol. Process., 21, 3233-3236, 2007.

Wagener, T., Sivapalan, M., Troch, P. A., McGlynn, B. L., Harman, C. J., Gupta, H. V., Kumar, P., Rao, P. S. C., Basu, N. B., and Wilson, J. S.: The future of hydrology: An evolving science for a changing world, Water Resour. Res., 46, W05301, doi:10.1029/2009WR008906, 2010.

Wahren, A., Schwärzel, K., Feger, K. H., Münch, A., and Dittrich, I.: Identification and model based assessment of the potential water retention caused by land-use changes, Adv. Geosci., 11, 4956, doi:10.5194/adgeo-11-49-2007, 2007.

Wegehenkel, M.: Estimating of the impact of land use changes using the conceptual hydrological model THESEUS-a case study, Phys. Chem. Earth, 27, 631-640, 2002. 